\title{
Legendre の多項式を用いた折板構造の一振動解析 \\ A VIBRATION ANALYSIS ON FOLDED PLATE STRUCTURES BY LEGENDRE POLYNOMIALS
}

\author{
水上隆 男*・西岡隆** \\ By Takao MIZUKAMI and Takashi NISHIOKA
}

\section{1. まえがき}

これまでの研究によれば, 板要素あるいは板要素を構 成要素とする構造物の振動近似解法を取り扱った論文は 多い.たとえば，面外変形を受ける平板の近似解法につ いての論文としては，3)〜6) が挙げられる。Leisso ${ }^{3)}$ は, 静的な問題について種々の近似解法の精度の検討を している. Warburton ${ }^{4)}$ は, はりの固有関数の積の和で 変位関数を仮定し, Rayleigh の原理で固有振動数を求 めている. Yang ${ }^{5)}$ は, 内部拘束のある板の振動問題を 論じている. 一方, Cheung ${ }^{6)}$ は, 有限帯板法により種 々の境界条件を有する平板の振動問題を論じている.

立体的な折板構造として薄肉はりの動的問題を取り扱 った最近の論文としては, たとえば中村 ${ }^{7)}$ と能町ら ${ }^{8)}$ の 論文が挙げられる. 中村は, 有限帯板法を用いて, 面内 変形作用と面外変形作用をともに考慮した薄肉はりの振 動解析を行っている. 彼は一つの要素内で長手方向の軸 に直交する面内方向成分を低次の多項式で近似したた め, 一つの要素で表現できる変形には制限がある. その ため分割数が少ないと断面変形が拘束され, 固有振動数 が実際の值より高くなるものと思われる. また, 分割数 が多すぎると固有マトリックスの階数が高くなり, 固有 值計算上の精度が低下することが考えられる．これらの 問題は一連の有限要素法解析 ${ }^{9)}{ }^{10)}$ に共通した問題である と思われる. 能町ら ${ }^{8)}$ は, 薄肉はりの弾性波の位相速度 について論じている. 彼は, はりの軸方向について進行 波の波形を仮定し, 直交方向については, 波形を仮定せ ずに有限フーリエ変換により解析している. したがっ て, 有限要素法 (有限帯板法) 7 (9),10)などの近似解法と 比べて変位関数の選択や精度の向上のための分割数の問 題は生じないが, 基礎微分方程式を忠実に解いているた

\footnotetext{
* 正会員 工修 鹿島建設 (株) 土木工務部

** 正会員 工博 東京大学助教授 工学部土木工学科
}

め解析法が非常に複雑になる. また, 固有值が固有マト リックスの中に複雑に入り込み分離できないので, 数值 計算が困難になるものと思われる.

本論文では前記の有限要素法的な近似解法と有限フー リエ変換等を用いた解析的な手法の問題点に考慮を払 い, 重みつき残差法に 基づく解法を提示する.すなわ ち, 変位関数を直交関数で仮定することにより幾何学的 に連続的な板を細分することなく，多くの自由度を有す る長方形板として解析する. それらの要素を境界で座標 変換マトリックスを用いて連続条件で接合すれば, 折板 構造を解析することができる. しかも直交関数として収 束性のよい級数を用いることにより変位関数を有限個の 項数で十分精度よく近似することが 可能になる.さら に, 固有方程式を線形な形で与えることができ, 有限な 自由度で固有值解析を行うことができる.ここでは数值 解析例として種々の境界条件を有する長方形板について 固有振動数を求め古典的理論解 ${ }^{11,2)}$ との比較を行い, さ らに立体的な折板構造としてボックスガーターを例にと り, 振動モードについて解析した.

\section{2. ルジャンドルの多項式を試行関数に用いた} 重みつき残差法

弹性体が微小変位する場合, その平衡状態を記述する 解は応力のつりあい条件式, ひずみ一変位関係式および 弾性体としての応力ーひずみ関係式を 満足するただ一つ の解である、ここで上記の三条件は変位 $\boldsymbol{u}$ または内力 $\boldsymbol{r}$ に関する連立偏微分方程式を与えるから, それを所定 の境界条件のもとに解くことが弾性学の主要な課題とな っている.しかし, 解析的な手法で解ける問題の範囲は 限られており, 工学的な見地で問題を解決するためには 近似解によらなければならないことが多い。この近似解 は一般に与えられた問題に付随する条件のすべてを満足 させることはできない. そこで現在一般的に用いられて 
いる有限要素法, 有限帯板法では, 与えられた問題の現 象に考慮を払いながら，境界条件の一部あるいは全部を 満足するような有限個の既知関数列で変位分布を仮定し ている. そして, その際に導入される末定係数を限られ た自由度の範囲で最適に決定するための近似解法の一つ として, 重みつき残差法が用いられてきた ${ }^{11)}$ (13).

しかし, その反面重みつき残差法は, 残差の重みつき 平均を零とするため, 仮定する試行関数や重み関数の良 否が解の精度に大きな影響を与えるといら問題が残る. そのため, 試行関数を仮定する際にはその問題の現象に 着目して適切な関数列を用いることが重要となる.

本論文で試行関数に採用した関数列は, 最初は境界条 件も微分方程式も満足しないが，あとから境界条件を満 足するように未定係数間の一次従属関係を決めているの で, 最終的には内部法 ${ }^{13)}$ の一種であると考えられる.

弾性体の振動モードは境界に囲まれた幾何学的に連続 な部分では，一般に与えられた境界条件を満足するよう な, なめらかな曲線となる. しかも弾性体のモード群 は，互いに直交する.したがって，有限要素法などのよ らに構造体を細分して, 各要素の試行関数を限られた項 数からなる低次の多項式で近似するよりは, あらかじめ 試行関数に高次の項まで含む直交関数列を用いた方が有 利であると思われる.

すなわち, 試行関数として不連続面での境界条件を満 足するような直交関数列を用いれば，その関数列が完全 系であるならば, 近似解を限りなく㛜密解に近づけるこ とができる．しかし，実際には無限項まで考慮すること は不可能であるので, 収束性のよい直交関数列を用いる ことが重要となる.

従来の振動解析では, 直交関数系の中でも特にフーリ エ級数が多く用いられてきた，両端が単純支持の場 合 は, フーリエ級数は静的問題でも動的問題でも威力を発 揮しかなりの成果を挙げることができる．ところがそれ 以外の境界值問題では, 収束性およびその取り扱いにお いて問題が多い，たとえば，フーリエ級数の特性 ${ }^{16), 17)}$ として両端の境界条件が等しくないと収束性が悪いばか りでなく微係数の一様収束性が一般には保証されない. しかも両端単純支持でないと, 一般に正弦級数と余弦級 数の和で試行関数を与えなりればならなくなり, その取 り扱いが複雑になる. 以上の理由から両端が単純支持の 場合を除いては, フーリエ級数は, 一般に試行関数とし て適当ではないと思われる.

ここではフーリエ級数の欠点を克服する直交関数とし

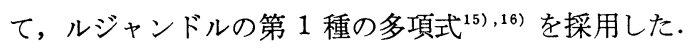
ルジャンドルの多項式

$$
P_{n}(X)=\frac{1}{2^{n} n !} \frac{d^{n}}{d X^{n}}\left(X^{2}-1\right)^{n}, \quad(n=0,1,2, \cdots)
$$

は, $|X| \leqq 1$ で直交性があり, しかも $P_{n}(1)=1, P_{n}$ $(-1)=(-1)^{n}$, また $|X|<1$ で $n$ 個の根を持つ. 直 交関数としてルジャンドルの多項式を領域 $|X| \leqq 1$ で 試行関数に用いる場合の有利な点は,

$$
P_{2 m+1}^{(-1)}=-P_{2 m+1}{ }^{(1)},(m=0,1,2, \cdots)
$$

となり, 奇数番目の項は両端の境界上 $(X= \pm 1)$ で值が 異なるため, 両端の境界条件が異なる場合でも真の境界 值を与えることが可能となることである. しかし，その 反面, ルジャンドルの多項式を試行関数として採用した 場合, $P_{n}(X)$ の導関数は三角関数のように回帰的でな いのでその定積分が複雑になる.この点については重み つき残差法を用いれば次のようにして解決できる.

すなわち, 試行関数をルジャンドルの多項式と末定係 数の 積の和として与え微分方程式に代入すれば, 残差 $R(X)$ が生じる. このとき重み関数としてディラック のデルタ関数を採用すれば, よく知られているように，

$$
\int_{-1}^{1} R(X) \cdot \delta\left(X-X_{i}\right) \cdot d X=R\left(X_{i}\right)=0
$$

となり, 定積分が容易に代数方程式に変換される.この とき, 試行関数に導入された未定係数を決定するため必 要十分なだけの領域内の異なる点 $X_{i}(i=1,2, \cdots)$ を選 べば, 連立方程式を解くことにより最適解を求めること ができる。

上記の手法はルジャンドルの多項式を用いた選点法で あるが, 選点 $X_{i}$ を無限にふやせば領域内のすべての点 で微分方程式を満足することになり, 限りなく厳密解に 近ゔけることができる.ここで選点 $X_{i}$ の数を制限し， かつ収束性を高めるには, 選点 $X_{i}$ の選び方に制限を加 える必要がある. Finlayson ${ }^{11}$ によれば試行関数に直交 関数を用いた場合, 選点すなわち $X_{i}(i=1 \sim K)$ を $K$ 次 の直交関数の根に選べば低次の選点法の結果はいっそう 信頼できるものとなると述べている.すなわち, 選点 $X_{i}$ を $P_{k}\left(X_{i}\right)=0$ を満たすルジャンドルの多項式の根とす れば低次の近似でも精度をあげることが可能となる.

なお,ルジャンドルの多項式を用いた類似の研究とし ては Soler の論文 ${ }^{14)}$ が挙げられる. Soler は長方形板の 面内変形問題において面内応力と変位をルジャンドルの 多項式に展開寸る近似解法を提示している.

\section{3. 薄肉長方形板の境界值問題}

2 次元的な広がりを持つ薄板で，その厚さが幅または 長さのディメンションに比べて小さく，その厚さが一様 であり，板の中央面が平面であるような長方形板の運動 方程式を以下の仮定に基づいて与える.

（i）平板がたわむ前に中央面に垂直であった平面 は, 変形後も中央面に対して垂直な平面を保っ. 


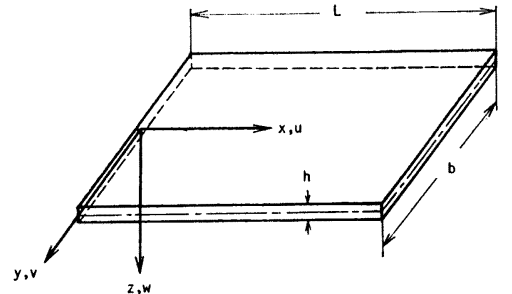

Fig. 1 Coordinate System and Rectangular Plate Element.

（ii）たわみ変形は，板厚に比べて小さいと仮定す る.

(iii）面内変形は, 板の幅または長さに比べてきわめ て小さいと仮定する.

(iv）振動の減衰は無視できるものとする.

以上の仮定上り一枚の長方形板要素について面内変形 と面外変形の連成を無視して, それぞれ独立に運動方程 式を与えることができる.任意の長方形板要素を Fig.1 の上うに右手座標系にとれば, 面外振動, 面内振動につ いての運動方程式は,

$$
\begin{aligned}
& \frac{\partial^{2} M_{x}}{\partial x^{2}}+2 \frac{\partial^{2} M_{x y}}{\partial x \partial y}+\frac{\partial^{2} M_{y}}{\partial y^{2}}-r \frac{\partial^{2} w}{\partial t^{2}}=F_{z}(x, y, t) \\
& \frac{\partial N_{x}}{\partial x}+\frac{\partial N_{x y}}{\partial y}-r \frac{\partial^{2} u}{\partial t^{2}}=F_{x}(x, y, t) \cdots \cdots \cdots \cdots(2) \\
& \frac{\partial N_{x y}}{\partial x}+\frac{\partial N_{y}}{\partial y}-r \frac{\partial^{2} v}{\partial t^{2}}=F_{y}(x, y, t) \cdots \cdots \cdots(3) \cdots \cdots(1)
\end{aligned}
$$

となる、ここで $r$ は単位面積あたりの質量であり, 密 度を $\rho$, 板厚を $h$ とすれば $r=\rho h$ で与えられる.また, $F_{z}, F_{x}, F_{y}$ は $z, x, y$ 方向の外力を表わしている.

式(1) でモーメント $M_{x}, M_{y}$, 㸚じりモーメント $M_{x y}$ と曲率の関倸は，仮定より次のように与えられる.

$$
\begin{aligned}
& M_{x}=-D\left(\frac{\partial^{2} w}{\partial x^{2}}+\nu \frac{\partial^{2} w}{\partial y^{2}}\right) \\
& M_{y}=-D\left(\frac{\partial^{2} w}{\partial y^{2}}+\nu \frac{\partial^{2} w}{\partial x^{2}}\right) \\
& M_{x y}=D(1-\nu) \frac{\partial^{2} w}{\partial x \partial y}
\end{aligned}
$$

ここで, vはポアソン比, $D$ は板の曲げ剛性で $D=\frac{E h^{3}}{12\left(1-\nu^{2}\right)}, E$ はヤング率, $h$ は板厚である.

また, 式 (2), (3) で軸方向力 $N_{x}, N_{y}$, せん断力 $N_{x y}$ は, 平面応力問題として,

$$
\begin{aligned}
N_{x} & =\frac{E h}{1-\nu^{2}}\left(\frac{\partial u}{\partial x}+\nu \frac{\partial v}{\partial y}\right) \\
N_{y} & =\frac{E h}{1-\nu^{2}}\left(\frac{\partial v}{\partial y}+\nu \frac{\partial u}{\partial x}\right) \\
N_{x y} & =\frac{E h}{2(1+\nu)}\left(\frac{\partial u}{\partial y}+\frac{\partial v}{\partial x}\right)
\end{aligned}
$$

で与えられる.

自由振動問題を取り扱う場合には式 (1)〜 (3) で $F_{x}=$
$F_{y}=F_{z}=0$ とおけばよい. 式(4)〜(9) を式(1)〜 (3) に 代入すれば, 長方形板要素の自由振動の運動方程式は, 変位 $u, v, w$ の偏微分方程式として以下のように与え られる.

$$
\begin{aligned}
& \nabla^{2} \nabla^{2} w+\frac{r}{D} \frac{\partial^{2} w}{\partial t^{2}}=0 \\
& \frac{\partial^{2} u}{\partial x^{2}}+\frac{1-\nu}{2} \frac{\partial^{2} u}{\partial y^{2}}+\frac{1+\nu}{2} \frac{\partial^{2} v}{\partial x \partial y}-\frac{r h^{2}}{12 D} \frac{\partial^{2} u}{\partial t^{2}}=0 \\
& \frac{\partial^{2} v}{\partial y^{2}}+\frac{1-\nu}{2} \frac{\partial^{2} v}{\partial x^{2}}+\frac{1+\nu}{2} \frac{\partial^{2} u}{\partial x \partial y}-\frac{r h^{2}}{12 D} \frac{\partial^{2} v}{\partial t^{2}}=0
\end{aligned}
$$

Fig. 1 のような局所座標系で与えられた長方形板は, $x=0, x=L, y= \pm \frac{b}{2}$ の 4 辺でそれぞれ境界条件が与え られる. このとき $x=0, x=L$ が単純支持されている 場合は, 試行関数を変数分離形で与えることができるの で, $y= \pm \frac{b}{2}$ 上での境界条件は, $y$ についての一変数関 数として与えることができる. これに対してその他の場 合は, 一般にすべての辺上で $x$ と $y$ についての 2 変数 関数として境界条件を与えなければならない。したがっ て, 相対する 2 辺が単純支持の場合と任意に支持条件を 与える場合では, 試行関数を変えて解析した方が有利で

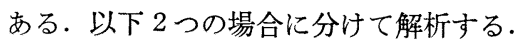

\section{（1） 相対する 2 辺が単純支持の長方形板の場合}

Fig. 1 で $x=0, L$ の境界が単純支持されているとき の長方形板の自由振動問題を式 (10) （12）を用いて解 析する.

$x=0, L$ 上の境界条件を満足する直交関数としてフー リエ級数を導入して試行関数 (変位関数) $u, v, w$ を次 のように仮定する.

$$
\begin{aligned}
w & =\sum_{n=1}^{\infty} \bar{W}_{n}(y, t) \cdot \sin \alpha_{n} \cdot x \\
u & =\sum_{n=1}^{\infty} \bar{U}_{n}(y, t) \cdot \cos \alpha_{n} \cdot x \cdot \\
v & =\sum_{n=1}^{\infty} \bar{V}_{n}(y, t) \cdot \sin \alpha_{n} \cdot x \cdot
\end{aligned}
$$

ただし， $\alpha_{n}=\frac{n \pi}{L}$

変位関数を前式のように仮定すれば，Fig. 1 で $y= \pm \frac{b}{2}$ 上の境界条件は，どのような条件であってもす べて変数分離形で与えることができる. 式 (13)〜 (15) を式（10)～(12) に代入してフーリエ級数の直交性を利 用すれば, 運動方程式は変数分離されて,

$$
\begin{gathered}
\alpha_{n}{ }^{4} \bar{W}_{n}-2 \alpha_{n}{ }^{2} \frac{\partial^{2} \bar{W}_{n}}{\partial y^{2}}+\frac{\partial^{4} \bar{W}_{n}}{\partial y^{4}}+\frac{r}{D} \frac{\partial^{2} \bar{W}_{n}}{\partial t^{2}}=0 \\
\ldots \ldots \ldots \ldots \ldots \ldots \ldots \ldots \ldots \ldots \ldots \ldots \ldots \ldots \ldots \ldots \ldots \ldots \ldots \ldots \ldots \\
\alpha_{n}{ }^{2} \bar{U}_{n}-\frac{1-\nu}{2} \frac{\partial^{2} \bar{U}_{n}}{\partial y^{2}}-\frac{1+\nu}{2} \alpha_{n} \frac{\partial \bar{V}_{n}}{\partial y}
\end{gathered}
$$




$$
\begin{gathered}
+\frac{r h^{2}}{12 D} \frac{\partial^{2} \bar{U}_{n}}{\partial t^{2}}=0 \ldots \ldots \ldots \ldots \ldots \ldots \ldots \ldots \ldots \ldots \ldots \ldots . . . \\
\frac{1-\nu}{2} \alpha_{n}{ }^{2} \bar{V}_{n}-\frac{\partial^{2} \bar{V}_{n}}{\partial y^{2}}+\frac{1+\nu}{2} \alpha_{n} \frac{\partial \bar{U}_{n}}{\partial y} \\
+\frac{r h^{2}}{12 D} \frac{\partial^{2} \bar{V}_{n}}{\partial t^{2}}=0 \ldots \ldots \ldots \ldots \ldots \ldots \ldots \ldots
\end{gathered}
$$

で与えられる.さらに仮定 (iv) より時間項を変数分離 すれば,

$$
\begin{aligned}
& \bar{W}_{n}(y, t)=W_{n}(y) \cdot e^{i \omega_{n} t} \\
& \bar{U}_{n}(y, t)=U_{n}(y) \cdot e^{i \omega_{n} t} \ldots \\
& \bar{V}_{n}(y, t)=V_{n}(y) \cdot e^{i \omega_{n} t} \ldots
\end{aligned}
$$

となる.ここで $\omega_{n}$ は $x$ 方向について $n$ 次の固有振動 数である. 前式を式 (16) （18）に代入すれば $y$ につい ての常微分方程式が得られる.

$$
\begin{aligned}
& \frac{d^{4} W_{n}}{d y^{4}}-2 \alpha_{n}{ }^{2} \frac{d^{2} W_{n}}{d y^{2}}+\left(\alpha_{n}{ }^{4}-\lambda^{4}\right) W_{n}=0 \ldots \\
& \frac{1-\nu}{2} \frac{d^{2} U_{n}}{d y^{2}}+\frac{1+\nu}{2} \alpha_{n} \frac{d V_{n}}{d y} \\
& \quad-\left(\alpha_{n}{ }^{2}-\frac{h^{2}}{12} \lambda^{4}\right) U_{n}=0 \\
& \frac{d^{2} V_{n}}{d y^{2}}-\frac{1+\nu}{2} \alpha_{n} \frac{d U_{n}}{d y} \\
& \quad-\left(\frac{1-\nu}{2} \alpha_{n}{ }^{2}-\frac{h^{2}}{12} \lambda^{4}\right) V_{n}=0
\end{aligned}
$$

ただし， $\lambda^{4}=\frac{r}{D} \omega_{n}^{2}$

上式を解くために， $W_{n}(y), U_{n}(y), V_{n}(y)$ を直交関 数に展開する. このとき $y= \pm \frac{b}{2}$ で変数分離形で与 え られる境界条件を完全に満足し，しかも収束性のよい関 数として，ルジャンドルの第一種の多項式を用いる. $W_{n}(y), U_{n}(y), V_{n}(y)$ をルジャンドルの多項式に展 開したとき，各項はそれぞれ $y= \pm \frac{b}{2}$ での境界条件を 満足する必要はなく, 展開した各項の総和が全体として 境界条件も満足すればよい. $W_{n}(y), U_{n}(y), V_{n}(y)$ に ついて，それぞれ $K$ 個の自由度を持たせるときは，満 足すべき境界条件の 個数を考虑にいれて, $W_{n}(y)$, は $K+4$ 項, $U_{n}(y), V_{n}(y)$ は $K+2$ 項で近似寸る. ᄂ たがって, 次のように与えられる.

$$
\begin{aligned}
W_{n}(y) & =\sum_{m=0}^{K+3} P_{m}(\beta y) \bar{w}_{m}(n) \\
U_{n}(y) & =\sum_{m=0}^{K+1} P_{m}(\beta y) \cdot \bar{u}_{m}(n) \\
V_{n}(y) & =\sum_{m=0}^{K+1} P_{m}(\beta y) \cdot \bar{v}_{m}(n)
\end{aligned}
$$

ただし, $P_{m}(X)=\frac{1}{2^{m} m !} \frac{d^{m}}{d X^{m}}\left(X^{2}-1\right)^{m}$

$$
\beta=\frac{2}{b}
$$

したがって, $|\beta y| \leqq 1$

以後簡単のために $\bar{w}_{m}(n), \bar{u}_{m}(n), \bar{v}_{m}(n)$ は，それぞ
れ $\bar{w}_{m}, \bar{u}_{m}, \bar{v}_{m}$ と略記する.

式 $(25) \sim(27)$ は, $W_{n(y)}, U_{n(y)}, V_{n(y)}$ をルジャン ドルの多項式に展開したとき，境界条件を満足させるこ とができる $K$ 次の近似式となるので, 式 (22)〜 (24)に 代入すれば微分方程式の残差が $y$ の関数として以下の ように定義できる.

$$
\begin{aligned}
& R_{w}(y)=\sum_{m=0}^{K+3}\left[\beta^{4} P_{m}^{m}(\beta y)-2 \alpha_{n}{ }^{2} \beta^{2} P_{m}^{\prime \prime}(\beta y)\right. \\
& \left.+\alpha_{n}{ }^{4} P_{m}(\beta y)-\lambda^{4} P_{m}(\beta y)\right] \bar{w}_{m} \\
& R_{u}(y)=\sum_{m=0}^{K+1}\left[\left\{\frac{1-\nu}{2} \beta^{2} P_{m}^{\prime \prime}(\beta y)-\alpha_{n}{ }^{2} P_{m}(\beta y)\right\}\right. \\
& \text { - } \bar{u}_{m}+\frac{1+\nu}{2} \alpha_{n} \beta P_{m}^{\prime}(\beta y) \bar{v}_{m} \\
& \left.+\frac{h^{2}}{12} \lambda^{4} P_{m}(\beta y) \bar{u}_{m}\right] \\
& R_{v}(y)=\sum_{m=0}^{K+1}\left[-\frac{1+\nu}{2} \alpha_{n} \beta P_{m}^{\prime}(\beta y) \bar{u}_{m}\right. \\
& +\left\{\beta^{2} P_{m}^{\prime \prime}(\beta y)-\frac{1-\nu}{2} \alpha_{n}^{2} P_{m}(\beta y)\right\} \\
& \text { - } \left.\bar{v}_{m}+\frac{h^{2}}{12} \lambda^{4} P_{m}(\beta y) \bar{v}_{m}\right]
\end{aligned}
$$

ここで残差 $R_{w}(y), R_{u}(y), R_{v}(y)$ に重み関数として ディラックのデルタ関数を掛けて積分し, 長方形板要素 の領域内で残差が零となるための未定係数 $\bar{w}_{m}, \bar{u}_{m}, \bar{v}_{m}$ の関係式を求める.

$$
\begin{aligned}
& \int_{-\frac{b}{2}}^{\frac{b}{2}} R_{w}(y) \delta\left(y-y_{i}\right)=R_{w}\left(y_{i}\right)=0 \\
& \int_{-\frac{b}{2}}^{\frac{b}{2}} R_{u}(y) \delta\left(y-y_{i}\right)=R_{u}\left(y_{i}\right)=0 \\
& \int_{-\frac{b}{2}}^{\frac{b}{2}} R_{v}(y) \delta\left(y-y_{i}\right)=R_{v}\left(y_{i}\right)=0 .
\end{aligned}
$$

ただし， $i=1 \sim K$

$K$ は任意に決められる自然数なので $K \rightarrow \infty$ とすれば, 選点法の性質から解は限りなく厳密解に近づく.

ここで式(31)〜 (33)における選点 $y_{i}(i=1 \sim K)$ を $K$ 次のルシャンドル多項式の根 $P_{K}(\beta y)=0$ にとれば, 先 に述べたように低次の近似でも精度をあげることが可能 になる. また, $P_{K}(\beta y)=0$ の根の分布は, $y=0$ を基 準にして対称に配置され, しかも $y= \pm \frac{b}{2}$ の境界に近 くなるほど密になる性質があるため, 境界值問題を解く 際に非常に有利であると考えられる. 式 (31)〜 (33) を マトリックスで表示すれば,

$$
\boldsymbol{a}_{1} \boldsymbol{x}_{1}+\boldsymbol{a}_{2} \boldsymbol{x}_{2}-\omega_{n}^{2}\left(\boldsymbol{c}_{1} \boldsymbol{x}_{1}+\boldsymbol{c}_{2} \boldsymbol{x}_{2}\right)=0
$$

ただし,$\quad x_{1}{ }^{T}=\left(\bar{u}_{0}, \cdots, \bar{u}_{K-1}, \bar{v}_{0}, \cdots, \bar{v}_{K-1}, \bar{w}_{0}, \cdots\right.$,

$$
\begin{aligned}
& \left.\bar{w}_{K-1}\right) \\
& \boldsymbol{x}_{2}{ }^{T}=\left(\bar{u}_{K}, \bar{u}_{K+1}, \bar{v}_{K}, \bar{v}_{K+1}, \bar{w}_{K}, \bar{w}_{K+1}, \bar{w}_{K+2},\right.
\end{aligned}
$$$$
\left.\bar{w}_{K+3}\right)
$$

となる ( $\boldsymbol{a}_{1}, \boldsymbol{a}_{2}, \boldsymbol{c}_{1}, \boldsymbol{c}_{2}$ は 付録 $\mathbf{A} \cdot 1$ を参照).

一枚の長方形板の振動は, 面外振動と面内振動とに分 
けて考えることができると仮定しているので，面外振動 のみを扱うときは, $\boldsymbol{e}_{5}, \boldsymbol{e}_{8}, \boldsymbol{f}_{5}, \boldsymbol{f}_{8}$ 以外のサブマトリック スを $\mathbf{O}$ マトリックスで置き換えればよい，これに対し ていくつかの板要素を連続条件で接合して薄肉はりなど の折板構造を解析するときは, 座標変換マトリックスを 用いて面外振動と面内振動を表示する成分をともに考虑 しなければならない（付録 $\mathbf{A} \cdot 1$ 参照).

式(34)で末定係数を列べクトル $\boldsymbol{x}_{1}$ と $\boldsymbol{x}_{2}$ に分けたの は， $x_{1}$ と $x_{2}$ は独立ではなく境界条件を介して一次従 属の関係があるからである．以下境界条件について述べ るが, 板要素を境界で接合するための連続条件について は次章に譲る.

Fig. 1 において $y= \pm \frac{b}{2}$ の境界上で板が固定, 自 由, あるいは単純支持されているときの境界条件を与 え, そのときの列ベクトル $x_{1}$ と $\boldsymbol{x}_{2}$ の関係式を求め る. 境界条件は，1つの境界線上で wについて 2 個, $u, v$ について 2 個あり, それらは次のように与えられ る.

固定端

$$
W_{n}(y)=0, W_{n}^{\prime}(y)=0, U_{n}(y)=0, V_{n}(y)=0
$$

自由端

$$
\begin{aligned}
& W_{n}^{\prime \prime}(y)-\nu \alpha_{n}{ }^{2} W_{n}(y)=0 \\
& W_{n}{ }^{\prime \prime}(y)-(2-\nu) \alpha_{n}{ }^{2} W_{n}{ }^{\prime}(y)=0 \\
& V_{n}{ }^{\prime}(y)-\nu \alpha_{n} U_{n}(y)=0 \\
& U_{n}^{\prime}(y)+\alpha_{n} V_{n}(y)=0
\end{aligned}
$$

単純支持

$$
\begin{aligned}
& W_{n}^{\prime \prime}(y)-\nu \alpha_{n}{ }^{2} W_{n}(y)=0 \\
& W_{n}(y)=0 \\
& V_{n}^{\prime}(y)-\nu \alpha_{n} U_{n}(y)=0 \\
& V_{n}^{\prime}(y)=0
\end{aligned}
$$

式 (35)〜 (37) に式 (25)〜 (27) を代入すれば列べクト ル $\boldsymbol{x}_{1}$ と $\boldsymbol{x}_{2}$ の関係式が与えられる（ただし， $\boldsymbol{b}_{1}, \boldsymbol{b}_{2}$, $b_{3}, b_{4}, b_{5}, b_{6}$ (付録 $\mathrm{A} \cdot 2$ 参照).

固定端

$$
\boldsymbol{b}_{1}(y) \boldsymbol{x}_{1}+\boldsymbol{b}_{2}(y) \boldsymbol{x}_{2}=0
$$

自由端

$$
\boldsymbol{b}_{3}(y) \boldsymbol{x}_{1}+\boldsymbol{b}_{4}(y) \boldsymbol{x}_{2}=0
$$

単純支持

$$
\boldsymbol{b}_{5}(y) \boldsymbol{x}_{1}+\boldsymbol{b}_{6}(y) \boldsymbol{x}_{2}=0
$$

Fig. 1 の長方形板で $y= \pm \frac{b}{2}$ が境界となるときは, 式 (38)〜（40）を適当に組み合わせればよい．たとえば， $y=\frac{b}{2}$ が自由端で, $y=-\frac{b}{2}$ が固定端の場合は次のよう になる。

$$
\left[\begin{array}{l}
b_{3}\left(\frac{b}{2}\right) \\
b_{1}\left(-\frac{b}{2}\right)
\end{array}\right] \boldsymbol{x}_{1}+\left[\begin{array}{l}
b_{4}\left(\frac{b}{2}\right) \\
b_{2}\left(-\frac{b}{2}\right)
\end{array}\right] \boldsymbol{x}_{2}=0
$$

上式を一般的に書けば，

$$
B_{1} x_{1}+B_{2} x_{2}=0
$$

となる.ここで $\boldsymbol{B}_{1}$ は $8 \times 3 \mathrm{~K}, \boldsymbol{B}_{2}$ は $8 \times 8$ のマトリッ クスである. したがって， $\boldsymbol{B}_{2}$ の逆マトリックスを求め れば， $x_{2}$ と $x_{1}$ の一次従属関係式が求まる.

$$
\boldsymbol{x}_{2}=-B_{2}^{-1} B_{1} x_{1}=D_{1} x_{1}
$$

式 (42) を式 (34) に代入して $\boldsymbol{x}_{2}$ を消去すれば, 振動数 方程式が得られ,

$$
\left(c_{1}+c_{2} D_{1}\right)^{-1}\left(a_{1}+a_{2} D_{1}\right) x_{1}-\omega_{n}^{2} I x_{1}=0 \cdots
$$

となる.ここで $I$ は, $3 K \times 3 K$ の単位マトリックスで ある。

式 (43) の固有值解析を行えば固有振動数 $\omega_{n}$ を求め ることができる.

\section{（2）任意支持長方形板の場合}

Fig. 2 に示すように $x= \pm \frac{L}{2}$ と $y= \pm \frac{b}{2}$ で境界条 件が任意に与えられる長方形板の面外振動について述べ る.

時間項を変数分離して変位関数を次のように仮定す る.

$$
w=\bar{W}(x, y) e^{i \omega t}
$$

上式を式 (10) に代入すれば,

$$
\frac{\partial^{4} \bar{W}}{\partial x^{4}}+2 \frac{\partial^{4} \bar{W}}{\partial x^{2} \partial y^{2}}+\frac{\partial^{4} \bar{W}}{\partial y^{4}}-\frac{\gamma}{D} \omega^{2} \bar{W}=0 \cdots
$$

となる. ここで 4 つの辺上の任意境界条件を満足させる ことができるように, 試行関数 (変位関数) $\bar{W}$ を $x$ 方 向, $y$ 方向の第一種のルジャンドルの多項式の積の和で 支える.このとき $x$ 方向の自由度を $N, y$ 方向の自由 度を $M$ とすれば, 境界条件の個数を考慮に入れて,

$$
\bar{W}(x, y)=\sum_{n=0}^{N+3} \sum_{m=0}^{M+3} P_{m}(\beta y) \cdot P_{n}(\alpha x) \bar{w}_{n m}
$$

ただし $, \quad \alpha=\frac{2}{L}, \beta=\frac{2}{b}$

となる. 上式を式 (45) に代入すれば残差 $R(x, y)$ が 定義される.

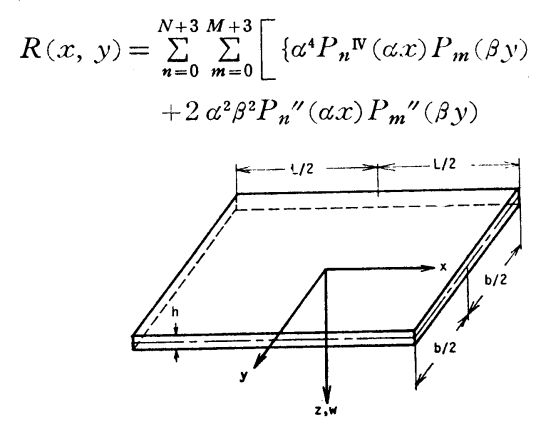

Fig. 2 Rectangular Plate Bending-Element considered Arbitrary Edge Conditions. 


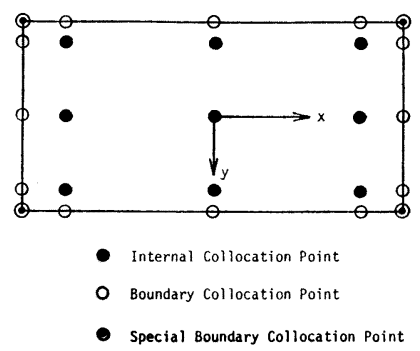

Fig. 3 Internal Collocation Point and Boundary Collocation Point (when $N=M=3$ )

$$
\begin{aligned}
& \left.+\beta^{4} P_{n}(\alpha x) P_{n}^{\mathrm{N}}(\beta y)\right\} \\
& \left.-\frac{\gamma}{D} P_{n}(\alpha x) P_{m}(\beta y) \omega^{2}\right] \bar{w}_{n m} .
\end{aligned}
$$

残差 $R(x, y)$ に重み関数 $g(x, y)$ を掛けて領域内 $\left(|x| \leqq \frac{L}{2},|y| \leqq \frac{b}{2}\right)$ で 2 重積分を行う. そして残差を 平均的に零と置くことにより，限られた自由度で最適な 解を求める. このとき積分が非常に複雑になるので選点 法を用いて 2 重積分を代数方程式に変換する.

すなおち, $g(x, y)=\delta\left(x-x_{i}\right) \cdot \delta\left(y-y_{j}\right)$ とおけば,

$$
\begin{aligned}
& \int_{-\frac{l}{2}}^{\frac{l}{2}} \int_{-\frac{b}{2}}^{\frac{b}{2}} R(x, y) \cdot \delta\left(x-x_{i}\right) \cdot \delta\left(y-y_{j}\right) d y \cdot d x \\
& =R\left(x_{i}, y_{j}\right)=0
\end{aligned}
$$

となる.ここで（1）と同様に $x_{i}(i=1 \sim N), y_{j}(j=1 \sim$ $M)$ をルジャンドルの多項式 $P_{N}(\alpha x)=0, P_{M}(\beta y)=0$ の根とすれば低次の近似でもよい結果が得られる.

Fig. 3 に示したように内部選点で式 (48) を満足さ せ, 境界選点で境界条件を満足するような解を求める. このとき境界選点で 2 個, 四隅の境界選点で 4 個（とな りあう2 辺が固定一固定, 固定一単純支持, あるいは単 純支持一単純支持の組み合せとなるときは 3 個）の境界 条件を満足させる. 内部選点は $N \times M$ 個, 境界選点は $2 \times(M+N)$ 個, 四隅の境界選点は 4 個ある.したがっ て, 四隅の境界選点がそれぞれ 4 個の境界条件を満足す る場合には, 満足すべき境界条件の個数と式 (48) を満 足する方程式の個数の和は， $(M+4) \times(N+4)$ 個とな り, 式 (46) で導入した未定係数の数と一致する. その 他の場合は, 式 (46) で適当に末定係数の数を増減させ て方程式の数と末定係数の数を一致させなければならな w.

式（48）をマトリックス表示すれば次のようになる.

$$
a_{3} x_{3}+a_{4} x_{4}-\omega^{2}\left(c_{3} x_{3}+c_{4} x_{4}\right)=0
$$

ただし，

$$
\begin{gathered}
\boldsymbol{x}_{3}{ }^{T}=\left(\bar{w}_{0,0}, \bar{w}_{0,1}, \bar{w}_{1,0}, \bar{w}_{0,2}, \bar{w}_{1,1}, \cdots, \bar{w}_{N-2, M-1},\right. \\
\left.\bar{w}_{N-1}, M-1\right) \\
\boldsymbol{x}_{4}{ }^{T}=\left(\bar{w}_{0, M}, \cdots, \bar{w}_{N+3}, M, \bar{w}_{0, M+1}, \cdots, \bar{w}_{N+3},\right. \\
\left.M+1, \bar{w}_{0, M+2}, \cdots, \bar{w}_{N+3, M+3}\right) \\
\left(\boldsymbol{a}_{3}, \boldsymbol{a}_{4}, \boldsymbol{c}_{3}, \boldsymbol{c}_{4} \text { は 付録 } \mathbf{A} \cdot 3 \text { を参照のこと }\right)
\end{gathered}
$$

ここで末定係数 $w_{n m}$ を $\boldsymbol{x}_{3}$ と $\boldsymbol{x}_{4}$ の 2 つのベクトル に分割したのは， $x_{3}$ と $x_{4}$ が一次独立ではなく境界条 件を介して一次従属な関係があるからである.

境界条件については，すべての境界線上 $\left(x= \pm \frac{L}{2}\right.$, $\left.y= \pm \frac{b}{2}\right)$ で境界条件を満足させることはできないの で, 境界選点上でのみ所定の境界条件を満足させる. な お境界選点は， $x= \pm \frac{L}{2}$ 上においては $P_{M}(\beta y)=0$ の 根および $y= \pm \frac{b}{2}, y= \pm \frac{b}{2}$ 上では $P_{N}(\alpha x)=0 \quad$ の根 および $x= \pm \frac{L}{2}$ とする.ここで境界選点では任意の境 界条件を満足させることが仃能である. 境界選点が満足 する種々の境界条件と, そのときの列ベクトル $\boldsymbol{x}_{3}$ と $\boldsymbol{x}_{4}$ の一次従属関係を付録 $\mathrm{A} \cdot 4$ に示す. 付録 $\mathrm{A} \cdot 4$ で $\boldsymbol{x}_{3}$ と $\boldsymbol{x}_{4}$ にかかる行ベクトル $\boldsymbol{b}_{7}$ と $\boldsymbol{b}_{8}, \boldsymbol{b}_{9}$ と $\boldsymbol{b}_{10}, \boldsymbol{b}_{11}$ と $b_{12}, b_{13}$ と $b_{14}, b_{15}$ と $b_{16}, b_{17}$ と $b_{18}$ は, それぞれ要 素数および添字 $n, m$ が異なるだけで各要素は, 同一の 式で表わすことができる.

次に Fig. 2 で $x= \pm \frac{L}{2}$ が固定で $y= \pm \frac{b}{2}$ が自由端 となるときの系全体の境界条件を例として以下に示寸.

$$
\left[\begin{array}{c}
\vdots \\
\boldsymbol{b}_{7}\left(\frac{L}{2}, y_{i}\right) \\
\vdots \\
\boldsymbol{b}_{7}\left(-\frac{L}{2}, y_{i}\right) \\
\vdots \\
\boldsymbol{b}_{9}\left(\frac{L}{2}, y_{i}\right) \\
\vdots \\
\boldsymbol{b}_{9}\left(-\frac{L}{2}, y_{i}\right) \\
\vdots \\
\boldsymbol{b}_{17}\left(x_{i}, \frac{b}{2}\right) \\
\vdots \\
\boldsymbol{b}_{17}\left(x_{i},-\frac{b}{2}\right) \\
\vdots \\
\boldsymbol{b}_{19}\left(x_{i}, \frac{b}{2}\right) \\
\vdots \\
\boldsymbol{b}_{19}\left(x_{i},-\frac{b}{2}\right)
\end{array}\right] \boldsymbol{x}_{3}+\left[\begin{array}{c}
\vdots \\
\boldsymbol{b}_{8}\left(\frac{L}{2}, y_{i}\right) \\
\vdots \\
\boldsymbol{b}_{8}\left(-\frac{L}{2}, y_{i}\right) \\
\vdots \\
\boldsymbol{b}_{10}\left(\frac{L}{2}, y_{i}\right) \\
\vdots \\
\vdots \\
\boldsymbol{b}_{18}\left(x_{i}, \frac{L}{2}\right) \\
\vdots \\
\boldsymbol{b}_{18}\left(x_{i},-\frac{b}{2}\right) \\
\vdots \\
\boldsymbol{b}_{20}\left(x_{i}, \frac{b}{2}\right) \\
\vdots \\
\boldsymbol{b}_{20}\left(x_{i},-\frac{b}{2}\right)
\end{array}\right] \boldsymbol{x}_{4}=0
$$

ただし， $x_{i}$ は $P_{N}(\alpha x)=0$ の根および $x= \pm \frac{L}{2}$

$$
\begin{array}{r}
(i=1 \sim N+2) \\
y_{i} \text { は } P_{M}(\beta y)=0 \text { の根および } y= \pm \frac{b}{2} \\
(j=1 \sim M+2)
\end{array}
$$

前式を一般的に書けば,

$$
B_{3} x_{3}+B_{4} x_{4}=0
$$

となる. ここで $\boldsymbol{B}_{3}$ は $4(M+N+4) \times M N, \boldsymbol{B}_{4}$ は $4(M$ $+N+4) \times 4(M+N+4)$ の正方マトリックスとなる. $B_{4}$ の逆マトリックスを求めれば, $x_{3}$ と $x_{4}$ の一次従属 関係式が得られる. 
$\boldsymbol{x}_{4}=-B_{4}^{-1} B_{3} x_{3}=D_{2} x_{3}$

式 (51) を式 (49) に代入して $x_{4}$ を消去すれば, 振動 数方程式が得られ，

$$
\left(\boldsymbol{c}_{3}+\boldsymbol{c}_{4} \boldsymbol{D}_{2}\right)^{-1}\left(\boldsymbol{a}_{3}+\boldsymbol{a}_{4} \boldsymbol{D}_{2}\right) \boldsymbol{x}_{3}-\omega^{2} \boldsymbol{I} \boldsymbol{x}_{3}=0
$$

となる.ここで $I$ は $M \cdot N \times M \cdot N$ の単位マトリックス である。

式（52）を解けば任意境界条件を有する長方形板の固 有振動数を求めることができる.

ここでは一例として長方形板の面外振動について述べ たが，同様な手法で面内振動や内部拘束を有寸る板の振 動問題 ${ }^{5}$ にも㹡張することができる.

\section{4. 折板構造への適用}

ここでは数枚の長方形板要素から構成されている折板 構造の振動解析に適用した場合について述べる. 取りあ げた構造体は両端が剛なダイヤフラムで補強されたボッ クスガーダーとした. ダイヤフラムの面内剛性を無限 大, 面外剛性を零と仮定し, 各長方形板要素の両端の境 界条件は単純支持とする。

Fig. 4 に局所座標系と 全体座標系の関係を示した.

Fig. 4 の節線 $L_{i j}$ で 2 枚の板要素 $i, j$ を接合させる ための条件として, 力学的境界量と幾何学的境界量を考 慮する. 局所座標系 $\left(x_{i}, y_{i}, z_{i}\right)$ で定義された境界量 $\boldsymbol{F}_{i}(x, y, t), \boldsymbol{U}_{i}(x, y, t)$ と全体座標系 $(X, Y, Z)$ で定 義された節線 $L_{i j}$ 上の境界量 $\tilde{\boldsymbol{F}}_{i j}(X, Y, t), \tilde{\boldsymbol{U}}_{i j}(X$, $Y, t)$ を以下のように与える.

$$
\begin{aligned}
& \boldsymbol{F}_{i}(x, y, t)^{T}=\left[N_{x y}{ }^{i}, N_{y}{ }^{i}, V_{y}{ }^{i}, M_{y}{ }^{i}\right] \cdots \\
& \boldsymbol{U}_{i}(x, y, t)^{T}=\left[u_{i}, v_{i}, w_{i}, \frac{\partial w_{i}}{\partial y}\right] \cdots \cdots \cdots \\
& \tilde{\boldsymbol{F}}_{i j}(X, Y, t)^{T}=\left[N_{X Y}{ }^{i}, N_{Y}{ }^{i}, V_{Y}{ }^{i}, M_{Y}{ }^{i}\right]
\end{aligned}
$$

$$
\tilde{\boldsymbol{U}}_{i j}(X, Y, t)^{T}=\left[u_{i j}, v_{i j}, w_{i j}, \frac{\partial w_{i j}}{\partial Y}\right]
$$

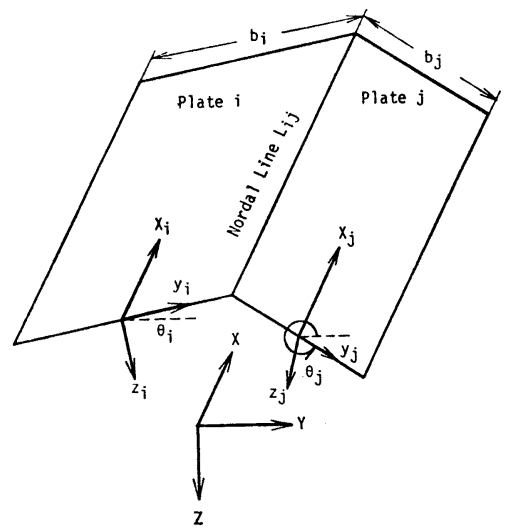

Fig. 4 Global Coordinate System and Local Coordinate Systems.
局所座標系を全体座標系に変換するための座標変換マ トリックス $\boldsymbol{T}_{i}$ は, 次のようになる.

$$
\boldsymbol{T}_{i}=\left[\begin{array}{cccc}
1 & 0 & 0 & 0 \\
0 & \nu_{i} & \mu_{i} & 0 \\
0 & -\mu_{i} & \nu_{i} & 0 \\
0 & 0 & 0 & 1
\end{array}\right]
$$

ただし， $\nu_{i}=\cos \theta_{i}, \mu_{i}=\sin \theta_{i}$

以上より節線 $L_{i j}$ 上の境界条件は次式で与えられる。

$$
\begin{gathered}
\tilde{\boldsymbol{F}}_{i j}=\left.\boldsymbol{T}_{i} \boldsymbol{F}_{i}\right|_{y_{i}=\frac{b_{i}}{2}}+\left.\boldsymbol{T}_{j} \boldsymbol{F}_{j}\right|_{y_{j}=-\frac{b_{j}}{2}}=0 \\
\tilde{U}_{i j}=\left.\boldsymbol{T}_{i} \boldsymbol{U}_{i}\right|_{y_{i}=\frac{b_{i}}{2}}=\left.\boldsymbol{T}_{j} \boldsymbol{U}_{j}\right|_{y_{j}=-\frac{b_{j}}{2}} \cdots \cdots
\end{gathered}
$$

ただし, 節線 $L_{i j}$ 上で外力 $\tilde{\boldsymbol{f}_{i j}}$ が作用している場合 は式 (58) で $\tilde{\boldsymbol{F}}_{i j}=\tilde{\boldsymbol{f}}_{i j}$ とすればよい.ここで境界量 $\boldsymbol{F}_{i}, \boldsymbol{U}_{i}$ は, 式 (34) で定義した局所座標系のベクトル $\boldsymbol{x}_{1}{ }^{i}, \boldsymbol{x}_{2}{ }^{i}$ を用いて次のように表わすことができる.

$$
\begin{aligned}
\boldsymbol{F}_{i}(x, y, t)= & \sum_{n=1}^{\infty} \boldsymbol{S}_{n}(x)\left[\boldsymbol{q}_{n \cdot 1}{ }^{i}(y) \cdot \boldsymbol{x}_{1}{ }^{i}\right. \\
& \left.+\boldsymbol{q}_{n \cdot 2}{ }^{i}(y) \cdot \boldsymbol{x}_{2}{ }^{i}\right] e^{i \omega_{n} t} \ldots . \\
\boldsymbol{U}_{i}(x, y, t)= & \sum_{n=1}^{\infty} \boldsymbol{S}_{n}(x)\left[\boldsymbol{r}_{n \cdot 1}{ }^{i}(y) \cdot \boldsymbol{x}_{1}{ }^{i}\right. \\
& \left.+\boldsymbol{r}_{n \cdot 2}{ }^{i}(y) \cdot \boldsymbol{x}_{2}{ }^{i}\right] e^{i \omega n_{n} t} \ldots .
\end{aligned}
$$

ただし, $\boldsymbol{S}_{n}(x)=\left(\cos \alpha_{n} x, \sin d_{n} x, \sin \alpha_{n} x, \sin \alpha_{n} x\right)$, $d_{n}=\frac{n \pi}{L}$

$\boldsymbol{q}_{n \cdot 1}{ }^{i}, \boldsymbol{q}_{n}{ }_{2}{ }^{i}, \boldsymbol{r}_{n \cdot 1}{ }^{i}, \boldsymbol{r}_{n \cdot 2}{ }^{i}$ は 3. (1) の同様の手 法で求めることができる.

式(60)，(61)を式(58)，(59)に代入すれば $\left(\boldsymbol{x}_{1}{ }^{i T}, \boldsymbol{x}_{1}{ }^{j T}\right)$ 之 $\left(\boldsymbol{x}_{2}{ }^{i T}, \boldsymbol{x}_{2}{ }^{j T}\right)$ の一次従属関係式が求まる.

$$
\begin{aligned}
& {\left[\begin{array}{c:c}
\boldsymbol{T}_{1} \boldsymbol{q}_{n \cdot 1}{ }^{i}\left(\frac{b_{i}}{2}\right) & \boldsymbol{T}_{j} \boldsymbol{q}_{n \cdot 1}{ }^{j}\left(\frac{b_{j}}{2}\right) \\
\hdashline \boldsymbol{T}_{i} \boldsymbol{r}_{n \cdot 1}{ }^{i}\left(\frac{b_{i}}{2}\right) & \boldsymbol{T}_{j} \boldsymbol{r}_{n \cdot 1}{ }^{j}\left(\frac{b_{j}}{2}\right)
\end{array}\right]\left\{\begin{array}{l}
\boldsymbol{x}_{1}{ }^{i} \\
\boldsymbol{x}_{1}{ }^{j}
\end{array}\right\}} \\
& +\left[\begin{array}{c:c}
\boldsymbol{T}_{i} \boldsymbol{q}_{n \cdot 2}{ }^{i}\left(\frac{b_{i}}{2}\right) & \boldsymbol{T}_{j} \boldsymbol{q}_{n \cdot 2}{ }^{j}\left(\begin{array}{c}
b_{j} \\
2
\end{array}\right) \\
\hdashline \boldsymbol{T}_{i} \boldsymbol{r}_{n \cdot 2}{ }^{i}\left(\frac{b_{i}}{2}\right) & \boldsymbol{T}_{j} \boldsymbol{r}_{n \cdot 2}{ }^{j}\left(\frac{b_{j}}{2}\right)
\end{array}\right]\left\{\begin{array}{l}
\boldsymbol{x}_{2}{ }^{i} \\
\boldsymbol{x}_{2}{ }^{j}
\end{array}\right\}=0
\end{aligned}
$$

系全体のすべての節線について上式を計算し重ね合わ せれば系全体の連続条件式が求まる。

$$
\begin{aligned}
& B_{5} \boldsymbol{X}_{1}+\boldsymbol{B}_{6} \boldsymbol{X}_{2}=0 \\
& \text { ただし }, X_{1}{ }^{T}=\left(x_{1}{ }^{1 T}, x_{1}{ }^{2 T}, \cdots, x_{1}{ }^{M T}\right) \\
& X_{2}{ }^{T}=\left(x_{2}{ }^{1 T}, x_{2}{ }^{2 T}, \cdots, x_{2}{ }^{M T}\right) \\
& \boldsymbol{X}_{2}=-B_{6}{ }^{-1} B_{5} \boldsymbol{X}_{1}=D_{3} \boldsymbol{X}_{1}
\end{aligned}
$$

また, 系全体の運動方程式は, 式（34）を重ね合わせて 次のように与えられる.

$$
\boldsymbol{A}_{1} \boldsymbol{X}_{1}+\boldsymbol{A}_{2} \boldsymbol{X}_{2}-\omega_{n}^{2}\left(\boldsymbol{C}_{1} \boldsymbol{X}_{1}+\boldsymbol{C}_{2} \boldsymbol{X}_{2}\right)=0
$$
ただし， 
Table 1 Values of $\mu_{1 m}$ for Modes of a Rectangular Plates.

$K=10$

\begin{tabular}{|c|c|c|c|c|c|c|c|c|c|c|}
\hline \multirow{2}{*}{\begin{tabular}{l}
\multicolumn{1}{c}{$L / b$} \\
Mode \\
Number
\end{tabular}} & \multicolumn{2}{|c|}{0.5} & \multicolumn{2}{|c|}{1.0} & \multicolumn{2}{|c|}{2.0} & \multicolumn{2}{|c|}{3.0} & \multirow{2}{*}{$\frac{5.0}{\text { Author }}$} & \multirow{2}{*}{$\frac{10.0}{\text { Author }}$} \\
\hline & Author & Iguchi & Author & Iguchi & Author & Iguchi & Author & Iguchi & & \\
\hline 1 & 3.946 & 3.946 & 0.9759 & 0.9759 & 0.2409 & 0.2410 & 0.1066 & 0.1066 & 0.03824 & 0.009545 \\
\hline 2 & 4.736 & 4.736 & 1.635 & 1.635 & 0.6971 & 0.6972 & 0.4484 & 0.4484 & 0.2639 & 0.1308 \\
\hline 3 & 7.167 & & 3.721 & 3.721 & 2.672 & & 2.452 & & 2.335 & 2.284 \\
\hline 4 & 11.25 & & 7.628 & 7.628 & 6.608 & & 6.410 & & 6.307 & 6.263 \\
\hline 5 & 17.18 & & 13.55 & 13.55 & 12.58 & & 12.40 & & 12.30 & 12.26 \\
\hline
\end{tabular}

where. $\quad$ Boundary Condition

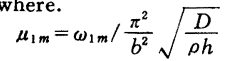

$m=$ Mode Number of y Direction

$K=$ Number of Collocation Points

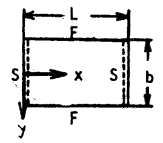

F: Free Edge

S: Simply Supported Edge

$$
\begin{aligned}
& \boldsymbol{A}_{1}=\left[\begin{array}{ccc}
\boldsymbol{a}_{1}{ }^{1} & & 0 \\
& \ddots & \\
\mathbf{0} & \boldsymbol{a}_{1}{ }^{M}
\end{array}\right] \quad \boldsymbol{A}_{2}=\left[\begin{array}{ccc}
\boldsymbol{a}_{2}{ }^{1} & & 0 \\
& \ddots & \\
\mathbf{0} & & \boldsymbol{a}_{2}{ }^{M}
\end{array}\right] \\
& C_{1}=\left[\begin{array}{ccc}
\boldsymbol{C}_{1}{ }^{1} & & 0 \\
& \ddots & \\
0 & & \boldsymbol{c}_{1}{ }^{M}
\end{array}\right] \quad \boldsymbol{C}_{2}=\left[\begin{array}{ccc}
\boldsymbol{C}_{2}{ }^{1} & & 0 \\
& \ddots & \\
0 & & \boldsymbol{c}_{2}{ }^{M}
\end{array}\right]
\end{aligned}
$$

ここで上つきの添字は板要素の番号を示す.

式 (65) に式 (64)を代入して $\boldsymbol{X}_{2}$ を消去すれば,

$$
\left(D_{3} C_{2}+C_{2}\right)^{-1}\left(D_{3} A_{2}+A_{1}\right) X_{1}-\omega_{n}^{2} I X_{1}=0
$$

となる.ただし，I は $3\left(K_{1}+\cdots+K_{M}\right) \times 3\left(K_{1}+\cdots+K_{M}\right)$ の単位行列であり, $K_{i}$ は板要素 $i$ の選点数である.

式 (66) の固有值解析を行えば, 固有振動数 $\omega_{n}$ とそ れに対応するモード $\boldsymbol{X}_{n, 1}$ が求められる.さらに式 (64) より一次従属なベクトル $\boldsymbol{X}_{n, 2}=\boldsymbol{D} \cdot \boldsymbol{X}_{n, 1}$ が求まる. した がって， $X_{n, 1}$ と $X_{n, 2}$ を用いることにより振動モード を決定することができる.

\section{5. 数值解析例}

式 (43), (52), (66) の固有行列は, 試行関数の未定係 数をべクトル量として取り扱っているため, 非対称実行 列となる. そこで, ガウスの消去法による同次変換で, 固有行列を Hessemberg 行列倿変換し, $Q R$ 法 ${ }^{21)}$ で固 有值解析を行った. 計算モデルの材料定数は， $E=2.1$ $\times 10^{6} \mathrm{~kg} / \mathrm{cm}^{2}, \nu=0.3, \rho=8.01 \times 10^{-6} \mathrm{~kg} \cdot \mathrm{sec}^{2} / \mathrm{cm}^{4}$ とし た.

\section{(1) 長方形板}

相対する 2 辺が単純支持の場合の解析例とし て，他端が自由境界となる長方形板の自由振動 問題を式 (43) を用いて解析した. なお, 選点 数は, $K=10$ とした.

面外振動（曲げ振動）について, 固有振動数 $\omega_{n m}$ に関する無次元量 $\mu_{m n}=\omega_{n m} / \frac{\pi^{2}}{b^{2}} \sqrt{\frac{D}{\rho h}}$ を 求め, 井口 ${ }^{1)}$ の解析結果と比較した. 井口は, 三角関数と双曲線関数を用いることにより, 式 （10）を厳密江解いている. 波数 $n=1$ のとき,
縦横比 $L / b$ に対応する $\mu_{1 m}$ を Table 1 亿示し, 正方 形板の波数 $n$ に対応する $\mu_{n m}$ を Table 2 に示した. 選点数 $K=10$ より, 10 個の固有值が求まるが，そのう ち 1 次から 5 次までの固有值を表に示した. Table 1, 2 から明らかなように, 固有振動数は, 井口の結果とほぼ 完全に一致した.

また, Table 2 で, $n=1$ のときの振動モードを Fig. 5 に示した. Fig. 5 では, A-A 断面の Z 方向の変位 モードを実線で示し，さらに $m$ 次のモード曲線の上に， $m-1$ 次のルジャンドルの多項式 $P_{m-1}(\beta y)$ を破線で 示してある.

Fig. 5 より $m$ 次のモードと $P_{m-1}(\beta y)$ の形状は, 非常によく似ている. 一般に波数 $n$ や縦横比 $L / b$ が変 われば，振動モードは，わずかながら変化するが，いず れの場合も同様の傾向があり, 特に次数 $m$ が小さいと き, $m$ 次のモードとルジャンドルの多項式 $P_{m-1}(\beta y)$ はよく似ている，以上のことより，両端が自由端の場 合, 試行関数のその方向の成分をルジャンドルの多項式 で近似することは，非常に有利であると思われる.

面内振動については, 正方形板の固有振動数 $\omega_{n}$ と その振動モードをFig. 6 に示した. Fig. 6 より面内 振動についても妥当な結果が得られている.

式（43）を用いて，他の境界条件についても種々の計

\begin{tabular}{|c|c|c|c|c|c|c|c|c|c|}
\hline \multirow{2}{*}{$m$} & \multicolumn{2}{|c|}{1} & \multicolumn{2}{|c|}{2} & \multicolumn{2}{|c|}{3} & \multirow{2}{*}{$\frac{4}{\text { Author }}$} & \multicolumn{2}{|c|}{5} \\
\hline & Author & Iguchi & Author & Iguchi & Author & Iguchi & & Author & Iguchi \\
\hline 1 & 0.9759 & 0.9759 & 3.946 & 3.946 & 8.915 & 8.915 & 15.88 & 24.85 & 24.85 \\
\hline 2 & 1.635 & 1.635 & 4.736 & 4.736 & 9.731 & 9.731 & 16.70 & 25.65 & - \\
\hline 3 & 3.721 & 3.721 & 7.167 & 7.167 & 12.37 & 12.37 & 19.44 & 28.46 & 28.46 \\
\hline 4 & 7.628 & 7.628 & 11.25 & 11.25 & 16.69 & 16.69 & 23.94 & 33.07 & - \\
\hline 5 & 13.55 & 13.55 & 17.18 & 17.18 & 22.77 & 22.77 & 30.20 & 39.49 & 39.49 \\
\hline & $\begin{array}{l}\text { re. } \\
n=\omega_{n m} / \\
m=\text { Mode } \\
K=\text { Numb }\end{array}$ & $\begin{array}{l}\frac{\pi^{2}}{b^{2}} \sqrt{\frac{D}{\rho}} \\
\text { Numbe } \\
\text { Numbe }\end{array}$ & $\begin{array}{l}h \\
\mathrm{r} \text { of } \mathrm{x} \\
\mathrm{r} \text { of } \mathrm{y}\end{array}$ & $\begin{array}{l}\text { rection } \\
\text { Points }\end{array}$ & $\mathrm{Bo}$ & undary & $\begin{array}{l}\text { F: Free } \\
\text { S: Simp }\end{array}$ & $\begin{array}{l}\text { e Edge } \\
\text { ply Suppo }\end{array}$ & rted Edge \\
\hline
\end{tabular}
算を行った. その結果, 選点数を $K$ とすれば, 固有マ トリックスの階数とは無関倸に， $[K / 2]$ 次以下の固有振 


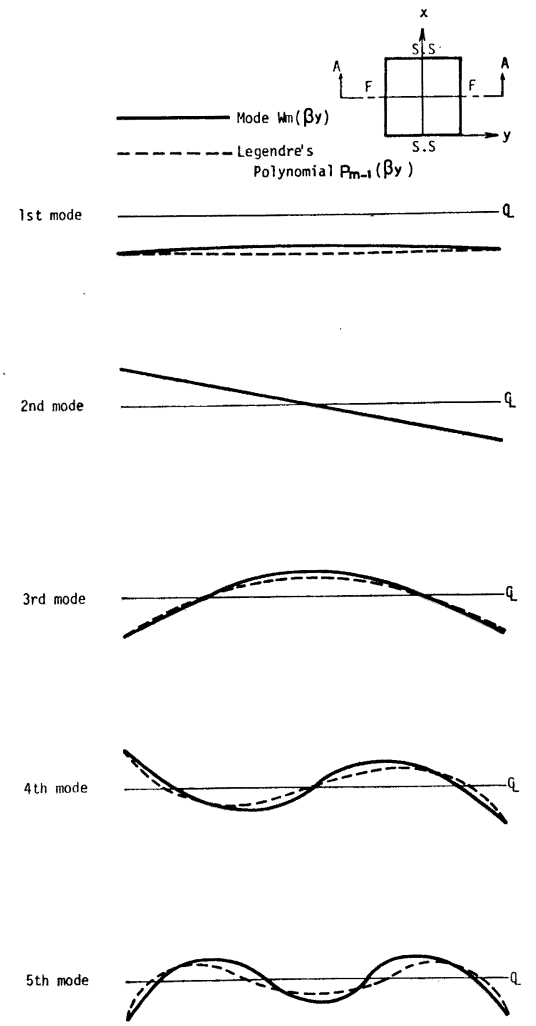

Fig. 5 Lateral Vibration Modes of Square Plate.

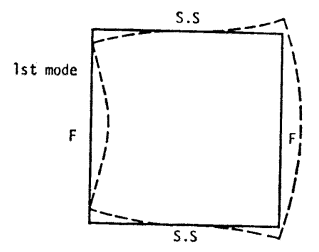

$\omega_{n}=7.555 \times 10^{3}$

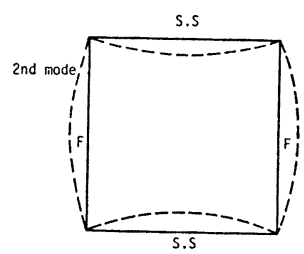

$\omega_{n}=1.411 \times 10^{4}$

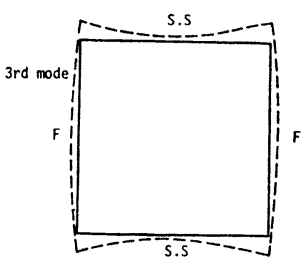

$\omega_{n}=1.806 \times 10^{4}$

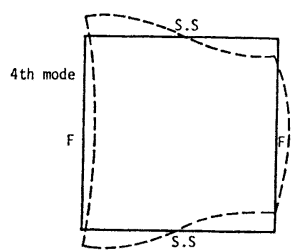

$\omega_{n}=1.878 \times 10^{4}$

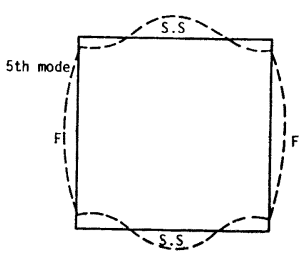

$\omega_{n}=2.702 \times 10^{4}$

Span : $L=100 \mathrm{~cm}$

Thickness : $h=1 \mathrm{~cm}$

Mode Number of S.S Direction : $n=1$

S.S : Simple Supported Edge

F : Free Edge

Fig. 6 In-Plane Vibration Modes and Natural Frequency $\omega_{n}$ of Square Plate.
動数に対しては，十分な精度が得られることがわかっ た. また， $[K / 2]$ 次より高次の固有振動数については， 精度が落ちる場合があるが，それは計算手法に問題があ るのではなく, 仮定した試行関数の最高次数により制限 をうけるからである.

任意支持長方形板の場合の解析例として，式（52）を 用いて, 相対する 2 辺が固定で他辺が自由となる正方形 板の曲げ振動問題を取り上げ, 固有振動数 $\omega_{n m}$ に関す る無次元量 $\mu_{n m}$ を求めた. 選点数は $M=K$ とし, $K=$ 7 と $K=8$ について $\mu_{n m}$ を求め, $K=8$ のときの $\mu_{n m}$ とWarburton ${ }^{4)}$ による $\mu_{n m}$ との相対誤差を Table 3 に示した. ここで $\mu_{n m}$ の添字 $n, m$ は, それぞれ $x$ 方 向, $y$ 方向の波数を示している.

Warburton は，板とはりの波形がそれぞれ類似して いると仮定し計算を行っている. そして所定の境界条件 を満足するはりの 2 方向の固有関数の積で, 板のモード を仮定し，Rayleigh の原理で固有振動数を求めている. したがって, 彼の理論では, 固有振動数は厳密解の上界 を与えることになり, しかも振動モードは, 固定端と単 純支持端では板としての境界条件を満足するが，自由端 では近似的にしか満足しないといら問題がある.

Table 3 より本解析法で求めた $\mu_{n m}$ は, すべて Warburton の值に比べて小さく, 相対誤差 $\varepsilon$ は, 0.4 $4 \%$ の範囲にある. 㛜密解は, Warburton の值より小 さいはずであるので, 厳密解に対して相対誤差を求めれ ば，ยはより小さくなると考えられる.

この計算手法は， $x$ 方向のルジャンドルの多項式と $y$ 方向のルジャンドルの多項式の積の和で試行関数を仮定 しているため，任意境界条件に対して適用できるという 利点があるが，その反面選点数が多くなると式 (51) で

Table 3 Comparisons of Proposed Analysis with G.B. Warburton's.

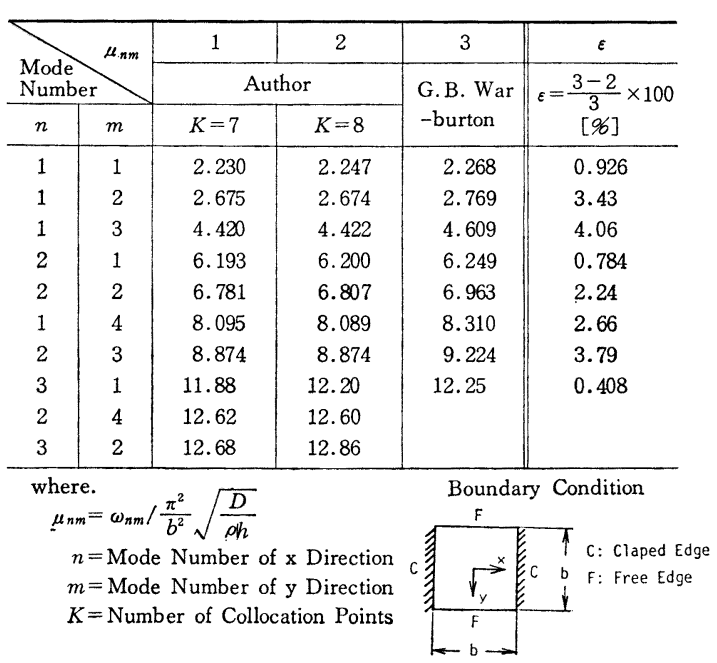


$B_{4}$ の階数が高くなり逆行列の計算で誤差が生じるとい う問題がある. それは、ルジャンドルの多項式の微分 $P_{N}{ }^{\prime}(x), P_{N^{\prime \prime}}(x), \cdots$ が, $N$ が大きくなると境界 $X=$ \pm 1 で急激に大きくなるため, $\boldsymbol{B}_{4}$ のマトリックスの中 で大きな数值と小さな数值がともに介在することになり 計算精度が落ちるからである。

この点に関しては，たとえば Table 3 で取り上げた ような対称な境界条件を有する問題では, 初めから対称 モードと逆対称モードに分けて計算することにより， $\boldsymbol{B}_{4}$ を $1 / 4$ あるいは $1 / 16$ の容量におとして計算し, 逆行列 の計算精度を高めることができる. その他の問題では, 一枚の板を数枚に分割することにより，ルジャンドルの 多項式の高次項の微係数を含まないような形で計算すれ ば, 精度のよい解が得られるものと思われる.

\section{（2）ボックスガーダー}

折板構造の解析例として, Fig. 7 に示すような両端 単純支持のボックスガーダーを 4 枚の板要素の集合体と 考え, 各板要素に $K$ 個の選点を配置し, 式 (66) を用 いて $12 \mathrm{~K}$ 自由度の固有值解析を行った. ボックスガー ダーの断面形状は, 板厚 $h_{w}=h_{f}=h$, 幅一高さ比 $B ! H=$ 1.5 , 高さ-板厚比 $H / h=30,300$, スパン-高さ比 $L / H=$ $0.5 \sim 20$ とした.

Fig. 8 にスパンー高さ比 $L / H=10, K=7$, 波数 $n=$ 1 の場合の基本的なモードを示す. Fig. 8 において, $a$ は厚肉 $(h / H=1 / 30), b$ は薄肉 $(h / H=1 / 300)$ の場合 の振動モードである. 断面変形はボックスガーダーの中 央で最大になり, 桁軸方向の面内変形は端部で最大にな るので, $x=L / 2$ での断面変形を実線で示し, $x=0$ で の桁軸方向の面内変位 $u$ を波線で示した. 面内変位 $u$ は, $u$ がプラスの時はボックス断面の内側に, $u$ がマイ ナスの時は外側に示した. ただし, 面内変形は, 比較的 大きなもののみ描いてある. Fig. 8 に示すように, 高 さ一板厚比が変われば同じ分類のモードでもその形状は 少しずつ異なる. この性質は, スパンー高さ比 $L / H$ や 波数 $n$ の変化に対しても見られる.

一般に構造体の振動モードは, その構造体の形状, 振 動の次数などによって異なる固有の関数である.したが って, 種々のパラメーターが変われば, モードも変化す るが,これらのモードを共通した特性を持つようなタイ

Fig. 7 Details of Box Girder.

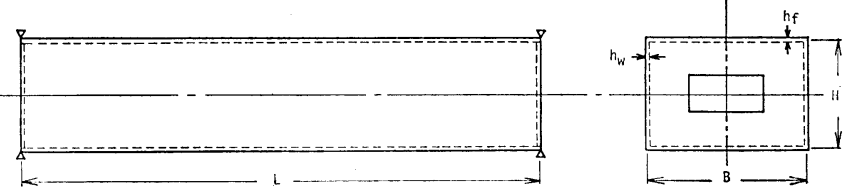

a: Thick $(\mathrm{h} / \mathrm{H}=1 / 30)$

b: Thin $(h / H=1 / 300)$

- Cross-Sectional Deformation at $x=L / 2$

- In-Plane Deformation at $x=0$
(1) - a

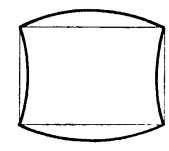

(2)- a

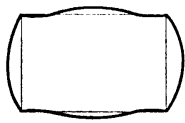

(3)- a

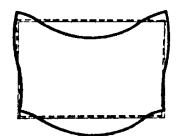

(4)- a

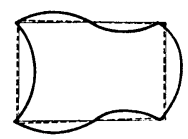

(5)

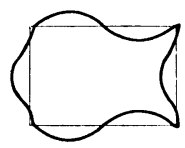

()-

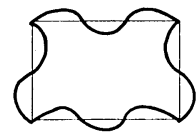

(1)-

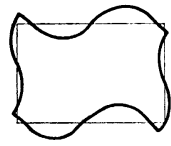

(ㄱ) - a

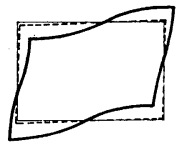

(9)-

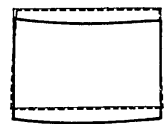

(11. -

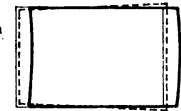

(11)

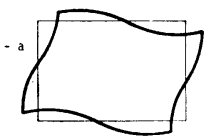

(17)

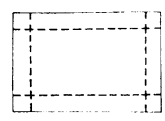

(1) -

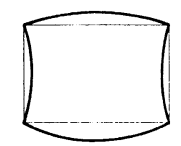

(2)

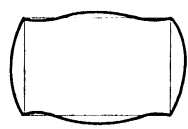

(3)-

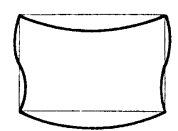

(4)-

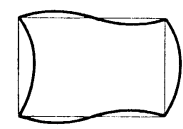

(5)-

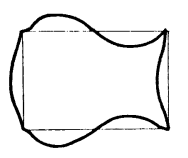

(๑)-

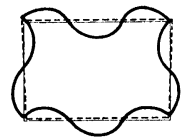

(7)-

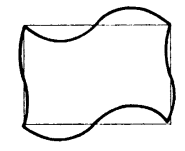

(8)-

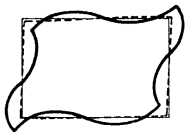

(9) -

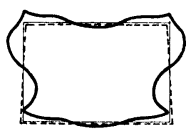

(10) -

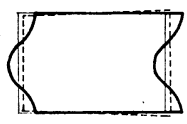

(11) -

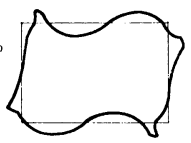

(1).

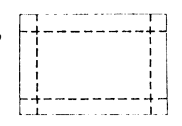

Fig. 8 Viblation Modes of Box Girder. 
Table 4 Vibration Modes of Box Girder.

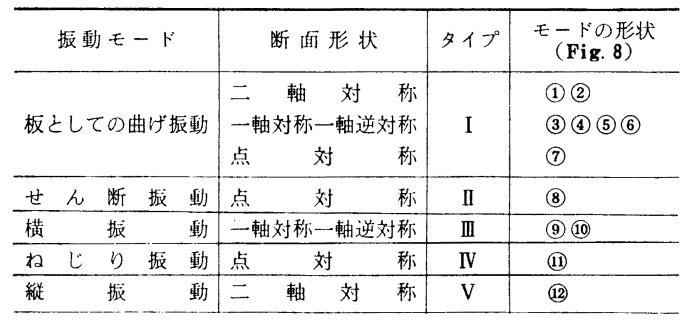

プに分類することは可能である.

すなわち, ボックスガーダーの振動モードを基本的な 板としての曲げ振動モード ( I ), せん断振動モード (II), および, はり理論に対応する横振動モード(III), ねじれ 振動モード(IV), 縦振動モード (V) に分類し, それら を Table 4 に示した.

Table 4 で板としての曲げ振動（I）とは, はりとし ての性質より, むしろ, 板としての性質が顕著であるよ うな振動を意味している．II，III，IV，Vのタイプに属す るモードは，タイプIに比べてはりとしての性質が顕著 である.タイプ II , III, IV は，板厚が薄くなるほど断面 変形が大きくなる傾向がある.これに対して, タイプV は，ほとんど断面変形を起こさない。

本解析法の収束性を検討するために, 選点数 $K$ に対 応する固有振動数 $\omega_{n}(K)$ の収束性を, $K=9$ の時の $\omega_{n}(9)$ に対する相対誤差として Table 5 に示した. た だし, 計算モデルは, 高さ-板厚比 $H / h=300$, スパンー 高さ比 $L / H=10$, そして, 波数は $n=1$ とした. また, Table 5 で各モードは, Fig. $8 b(H / h=300)$ に対応 している. Table 5 で, 11 番目のモードは, 他のモー ドに比べて収束性が悪い，それは計算モデルが非常に薄 肉 $(H / h=300)$ であるため, 断面変形が複雑になり, モ 一ドが高次関数で表現されるためであると思われる. 他

Table 5 Relative Error $\varepsilon$ of Natural Frequency $\omega$.

\begin{tabular}{|c|c|c|c|c|c|c|}
\hline$K$ & 3 & 4 & 5 & 6 & 7 & $\cdot 8$ \\
\hline $\begin{array}{c}\text { Mode } \\
\text { Type }\end{array}$ & 36 & 48 & 60 & 72 & 84 & 96 \\
\hline 1 & 0.776 & 0.000 & 0.000 & 0.000 & 0.000 & 0.000 \\
\hline 2 & 2.43 & -1.54 & 0.069 & 0.000 & 0.000 & 0.000 \\
\hline 3 & 1.39 & -0.232 & 0.077 & 0.000 & 0.000 & 0.000 \\
\hline 4 & -3.39 & 0.265 & -0.044 & 0.000 & 0.000 & 0.000 \\
\hline 5 & & 3.46 & -1.96 & 0.159 & 0.000 & 0.000 \\
\hline 6 & -8.53 & -14.5 & 3.13 & -1.18 & 0.121 & -0.015 \\
\hline 7 & -21.6 & 2.71 & -0.817 & 0.058 & 0.000 & 0.000 \\
\hline 8 & -22.9 & -0.763 & -0.661 & -0.182 & 0.034 & 0.000 \\
\hline 9 & 1.03 & -1.50 & 0.281 & -0.094 & 0.000 & 0.000 \\
\hline 10 & -19.6 & 1.04 & -0.471 & 0.075 & 0.000 & 0.000 \\
\hline 11 & 0.622 & -1.15 & 15.5 & 1.48 & 9.54 & 1.30 \\
\hline 12 & 0.280 & 0.037 & 0.075 & 0.056 & 0.037 & 0.279 \\
\hline
\end{tabular}

where.

$\varepsilon=\frac{\omega(9)-\omega(K)}{\omega(9)} \times 100 \%$

$\omega(K)=$ Natural Frequency when the Number of Collocation Points is $K$ $n=$ Mode Number of $\mathrm{x}$ Divection $N=$ Degree of Freedom
のモードについては $K \geqq 6$ で, ほぼ収束している.

Table 4 で分類したモードとその固有振動数 $\omega_{n}$ の 特性をさらに調べるために, スパン一高さ比 $L / H$ を変 えて種々の計算を行った. 固有振動数 $\omega_{n}$ に関する無次 元パラメーターは, タイプ I, II では $\mu_{n}=\omega_{n} / \frac{\pi^{2}}{H^{2}}$ $\sqrt{\frac{D}{\rho h}}$ を用いた。 ここで $\frac{\pi^{2}}{H^{2}} \sqrt{\frac{D}{\rho h}}$ は, 幅が $H$, ス パンが $L$, 板厚が $h$ で, $\left(\frac{L}{H}\right)^{2} \gg \pi^{2}$ なる関係を有する 四辺単純支持板の 1 次の固有振動数である. タイプIII は $\kappa_{n}=\omega_{n}\left(\frac{H}{L}\right)^{2} / \frac{\pi^{2}}{L^{2}} \sqrt{\frac{E I}{\rho A}}$, タイプ IV は $\eta_{n}=\omega_{n}\left(\frac{H}{L}\right) /$ $\frac{\pi}{L} \sqrt{\frac{G I}{\rho I_{p}}}$, タイプVは $\xi=\omega_{n}\left(\frac{H}{L}\right) / \frac{\pi}{H} \sqrt{\frac{E}{\rho}}$ を用いた. パラメーター $\kappa_{n}, \eta_{n}, \xi_{n}$ の分母は, それぞれスパン $L$ のボックスガーダーをはりの初等理論を用いて計算した 横振動, ねじり振動の 1 次の固有振動数である. したが って，パラメーター $\kappa_{n}, \eta_{n}, \xi_{n}$ の性質を調べれば断面 変形を考慮した本解析法とはり理論との比較をすること ができる.

計算結果は Fig. 9(a)〜（e）に示した. Fig. 9(a)〜 (e) はスパンー高さ比 $L / H$ が無次元化したそれぞれの固 有振動数に与える影響を表示したもので, 横軸にいずれ も $L / H$ をとり縦軸におのおの $\mu \kappa, \eta, \xi$ をとっている. 丸印に示した数字は Fig. 8 の各振動モードに対応する 番号を示している. また, Fig. 9(a)〜 (e) で, 無次元 パラメーター $\mu_{n}, \kappa_{n}, \eta_{n}, \xi_{n}$ は $H / h=300$ のときは実 線で, $H / h=30$ のときは破線で, そして初等はり理論 は一点鎖線で表している. Fig. 9（a）において破線で表 示された $H / h=30$ の場合には，板としての性質のほか に, はりとしての性質も表われるため, かならずしも単 調な曲線とはなっていない. しかし， $L / H<1$ の範囲で は板厚による相異はほとんど認められない.

Fig. 9(b) より, スパン一高さ比 $L / H$ が $1<L / H$

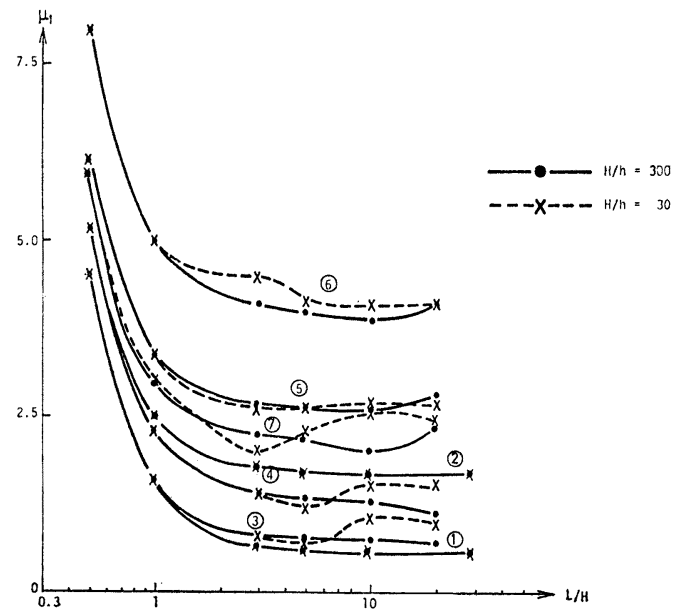

(a) Lateral Vibration Mode as Plate Element 


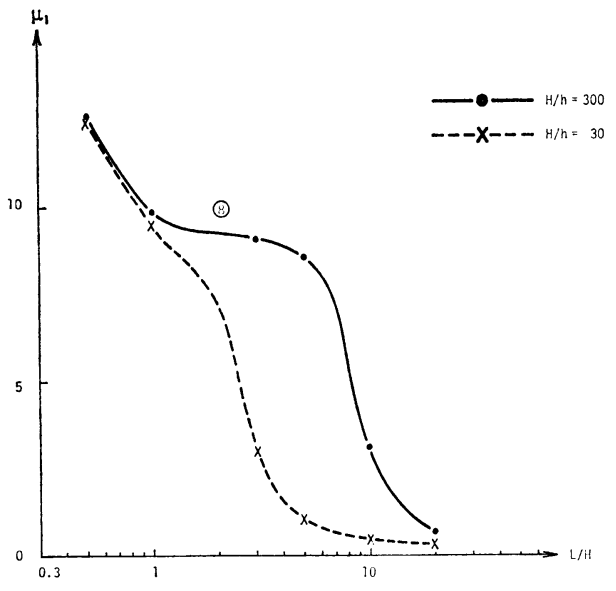

(b) Shear-Vibration of Cross-Section

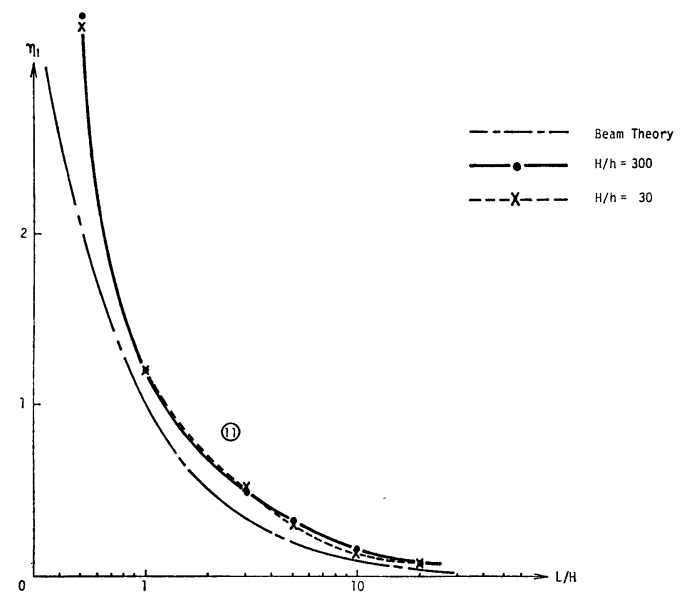

(d) Tortional Vibration

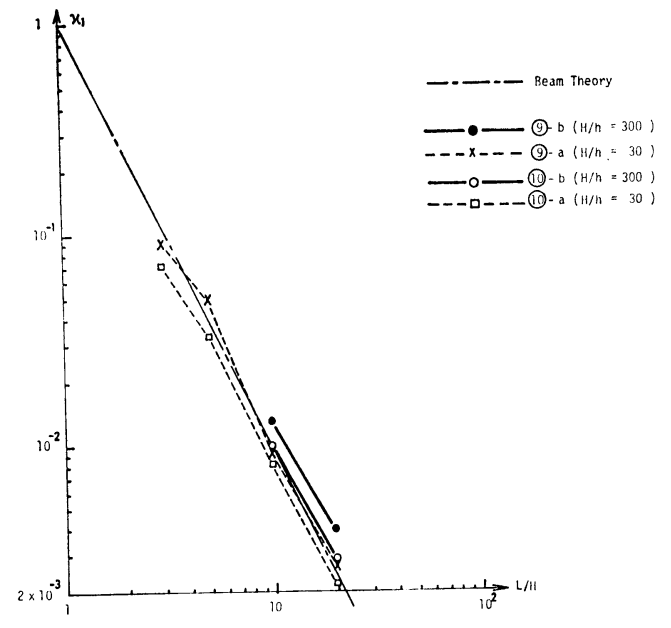

(c) Lateral Vibration

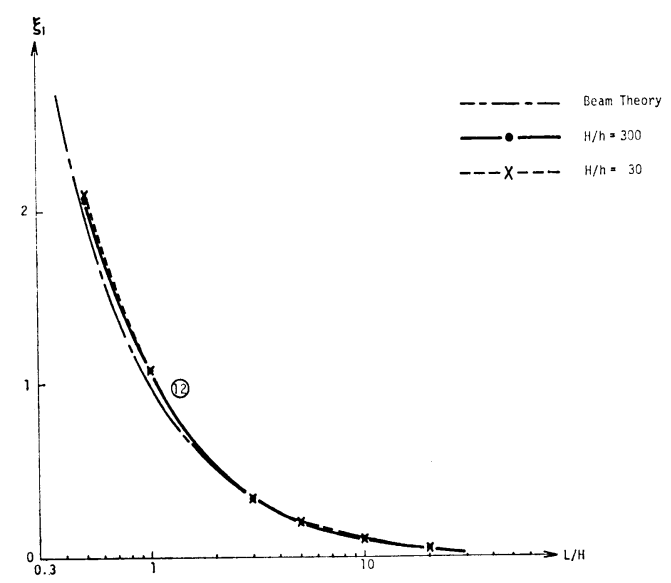

(e) Longitudinal Vibration

Fig. 9

<20 の範囲にあるときは，固有振動数は板厚に大きく 左右され, 振動モード（Fig. 8 8)） も大きく異なって いるため, 振動モードの判定が困難になる.しかし，ス パンが長くなり $L / H \geqq 20$ となると, 薄肉でも厚肉で もはりとしてのせん断変形が卓越し四隅の変位が大きく なる. 一方， $L / H \leqq 1$ となると板厚によらず四隅の変 位が零となり非常に複雑な断面変形が起こる.

Fig. 9(c) は Bernoulli-Euler ばりの横たわみ振動に 相当するモードである，はり理論による $\kappa_{1}$ と断面変形 を考慮に入れた本解析法の $\kappa_{1}$ とは一致しないが，厚肉 の場合は断面変形が小さいので， はり理論により $\kappa_{1}$ は ある程度の近似を与えている. 薄肉の場合は $L / H<10$ で, 厚肉の場合は $L / H<3$ で, 断面変形がさらに複雑 になるためモードの判別が困難となり，后が判定できな い. すなわち, $L / H$ が小さくなると複雑な断面変形が 起こり, はり理論に対応するような横振動モードは存在
しなくなる。

ねじり振動については Fig. 8 の (11) と Fig.9(d)よ り明らかなように, 薄肉であるほど断面変形が複雑であ るが，板厚が固有振動数に与える影響は小さいようであ る. しかし，本解析法で求めた $\eta_{1}$ は，St. Venant の ねじり理論による $\eta_{1}$ より大きく, 特に $L / H$ が小さい ときは，その差が大きい.

縦振動については Fig. 9(e) より， $\xi_{1}$ はスパンー高 さ比が $L / H<3$ のときを除けば，はり理論による值と ほぼ一致すると考えられる。

\section{6. 結論}

以上において各構成要素が面内変形ならびに面外変形 を受けるような折板構造に対してその動的挙動を解明す るために, ルジャンドルの第一種の多項式を試行関数と 
する解析理論を誘導し, 薄肉長方形板およびボックスガ ーダーの応用例を示した.

その結果，ルジャンドルの多項式は，相対する 2 辺が 自由端となる板の面外振動のモード成分に非常に近い関 数であるばかりでなく，任意境界条件を有する長方形板 に対しても少ない項数でモードを表現できること，直交 関数を試行関数に用いたため固有マトリックスの階数が 高い場合でも固有值計算の精度がよいこと，また，この 手法は，座標変換マトリックスを用いて連続条件を考慮 すれば, 立体的な折板構造に対しても容易に拡張できる ことなどが明らかとなった。

以上のことから，ルジャンドルの多項式を試行関数に 用いる本解析法は, 折板構造の動的挙動を解明するため の一般性および有用性をかねそなえた手法であると考え られる。

なお, 数值計算にあたって, 東京大学大型計算機セン ターHITAC 8800/8700 を用いて行われたものである ことを付記する.

\section{付録 A-1}

$$
a_{1}=\left[\begin{array}{lll}
e_{1} & e_{2} & 0 \\
e_{3} & e_{4} & 0 \\
0 & 0 & e_{5}
\end{array}\right] \quad c_{1}=\left[\begin{array}{ccc}
e_{6} & 0 & 0 \\
0 & e_{7} & 0 \\
0 & 0 & e_{8}
\end{array}\right]
$$

\section{付録 $\mathbf{A} \cdot 2$}

$$
\begin{aligned}
& \boldsymbol{b}_{1}(y)=\left[\begin{array}{cc:c}
\cdots, & P_{j-1}(\beta y), & \cdots \\
0 & \cdots, & P_{j-1}(\beta y), \\
0 & 0 \\
0 & 0
\end{array}\right.
\end{aligned}
$$

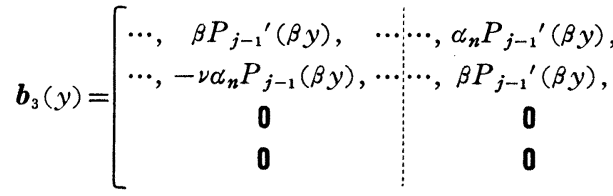

$$
\begin{aligned}
& \boldsymbol{b}_{5}(y)=\left[\begin{array}{c:cc}
\cdots,-\nu \alpha_{n} P_{j-1}(\beta y), \cdots, & \beta P_{j-1}{ }^{\prime}(\beta y), \\
0 & \cdots, & P_{j-1}(\beta y), \\
0 & 0 \\
0 & 0
\end{array}\right.
\end{aligned}
$$$$
\left.\begin{array}{c}
0 \\
0 \\
\cdots, P_{j-1}(\beta y), \cdots \\
\cdots, \beta P_{j-1}(\beta y), \cdots
\end{array}\right]
$$

$$
a_{2}=\left[\begin{array}{ccc}
f_{1} & f_{2} & 0 \\
f_{3} & f_{4} & 0 \\
0 & 0 & f_{5}
\end{array}\right] \quad c_{2}=\left[\begin{array}{ccc}
f_{6} & 0 & 0 \\
0 & f_{7} & 0 \\
0 & 0 & f_{8}
\end{array}\right]
$$

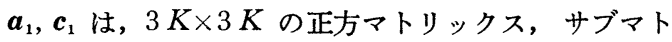
リックス $e_{1} \sim e_{8}$ は, $K \times K$ の正方マトリックスとなる また, $a_{2}, c_{2}$ は, $3 K \times 8$, サブマトリックス $\boldsymbol{f}_{1} \sim \boldsymbol{f}_{4}, \boldsymbol{f}_{6}$, $\boldsymbol{f}_{7}$ は, $K \times 2, \boldsymbol{f}_{5}, \boldsymbol{f}_{6}$ は $K \times 4$ のマトリックスとなる. サブマトリックス $\boldsymbol{e}_{\boldsymbol{m}}$ と $\boldsymbol{f}_{m}(m=1 \sim 8)$ の要素は, 添字 が異なるだけで同一の式で表現できるので, $\boldsymbol{e}_{m}$ の成分 のみを以下に示す.

$$
\begin{aligned}
& e_{i j}{ }^{1}= \frac{1-\nu}{2} \beta^{2} P_{j-1}^{\prime \prime}\left(\beta y_{i}\right)-\alpha_{n}^{2} P_{j-1}\left(\beta y_{i}\right) \\
& e_{i j}{ }^{2}= \frac{1+\nu}{2} \alpha_{n} \beta P_{j-1}{ }^{\prime}\left(\beta y_{i}\right) \\
& e_{i j}{ }^{3}=-e_{i j^{2}} \\
& e_{i j^{4}}= \beta^{2} P_{j-1}{ }^{\prime \prime}\left(\beta y_{i}\right)-\frac{1-\nu}{2} \alpha_{n}{ }^{2} P_{j-1}\left(\beta y_{i}\right) \\
& e_{i j}{ }^{5}= \beta^{4} P_{j-1}\left(\beta y_{i}\right)-2 \alpha_{n}{ }^{2} \beta^{2} P_{j-1}{ }^{\prime \prime}\left(\beta y_{i}\right) \\
&+\alpha_{j-1}{ }^{4}\left(\beta y_{i}\right) \\
& e_{i j}{ }^{6}= \frac{\left(1-\nu^{2}\right) \rho}{E} P_{j-1}\left(\beta y_{i}\right) \\
& e_{i j}{ }^{7}= e_{i j}{ }^{6} \\
& e_{i j}{ }^{8}= \frac{12(1-\nu)^{2} \rho}{E h^{2}} P_{j-1}\left(\beta y_{i}\right) \\
& \text { ただし, } e_{m}=\left[e_{i j}{ }^{m}\right] m=1 \sim 8, i=1 \sim K, j=1 \sim K
\end{aligned}
$$

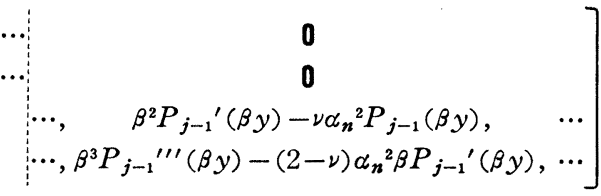

$$
\begin{aligned}
& \left.\begin{array}{c:cc}
\cdots & 0 & \\
\cdots & 0 & \\
\cdots, \beta^{2} P_{j-1}^{\prime \prime}(\beta y)-\nu \alpha_{n}{ }^{2} P_{j-1}(\beta y), \cdots
\end{array}\right]
\end{aligned}
$$

ただし， $j=1 \sim K$

$b_{1}$ と $b_{2}, b_{3}$ と $b_{4}, b_{5}$ と $b_{6}$ は, 添字 $j$ が異なるだ けで，同一の式で表現される. 寸なわち， $\bar{u}_{i}, \bar{v}_{i}$ に対応 する成分は, $j-1$ を $l+K-1(l=1,2), \bar{w}_{i}$ に対応す る成分は， $j-1$ を $m+K-1(m=1 \sim 4)$ とおきかえれ ば, $\boldsymbol{b}_{2}, \boldsymbol{b}_{4}, \boldsymbol{b}_{8}$ が与えられる。

\section{付録 $\mathbf{A} \cdot 3$}

$$
\begin{aligned}
\boldsymbol{a}_{3}= & {\left[\boldsymbol{f}\left(x_{1}, y_{1}\right), \cdots, \boldsymbol{f}\left(x_{N}, y_{1}\right), \boldsymbol{f}\left(x_{1}, y_{2}\right), \cdots,\right.} \\
& \left.\boldsymbol{f}\left(x_{N}, y_{M}\right)\right]^{T} \\
\boldsymbol{c}_{3}= & {\left[\boldsymbol{g}\left(x_{1}, y_{1}\right), \cdots, \boldsymbol{g}\left(x_{N}, y_{1}\right), \boldsymbol{g}\left(x_{1}, y_{2}\right), \cdots,\right.} \\
& \left.\boldsymbol{g}\left(x_{N}, y_{M}\right)\right]^{T}
\end{aligned}
$$


ただし， 行ベクトル $\boldsymbol{f}\left(x_{i}, y_{j}\right), \boldsymbol{g}\left(x_{i}, y_{j}\right)$ は要素数 $N \times M$ の行べクトルであり $, x_{i}, y_{i}$ はそれぞれ $P_{N}(\alpha x)$ $=0, P_{M}(\beta y)=0$ の根である. 行べクトル $\boldsymbol{f}\left(x_{i}, y_{i}\right)$, $\boldsymbol{g}\left(x_{i}, y_{i}\right)$ の $w_{n m}$ に対応する成分を以下に示す.

$$
\begin{aligned}
\boldsymbol{f}\left(x_{i}, y_{j}\right)= & {\left[\cdots, \alpha^{4} P_{n}^{\mathrm{IV}}\left(\alpha x_{i}\right) \cdot P_{m}\left(\beta y_{j}\right)\right.} \\
& +2 \alpha^{2} \beta^{2} P_{n}^{\prime \prime}(\alpha x) P_{m}^{\prime \prime}(\beta y) \\
& \left.+\beta^{4} P_{n}(\alpha x) P_{m}^{\mathrm{NV}}(\beta y), \cdots\right]
\end{aligned}
$$

$$
\boldsymbol{g}\left(x_{i}, y_{j}\right)=\left[\cdots,-\frac{\gamma}{D} P_{n}\left(\alpha x_{i}\right) \cdot P_{m}\left(\beta y_{j}\right), \cdots\right]
$$

ただし, $n=0 \sim N-1, m=0 \sim M-1$

マトリックス $\boldsymbol{a}_{4}, \boldsymbol{c}_{4}$ は上式で添字の $n m$ が異なり行

\begin{tabular}{|c|c|c|c|c|}
\hline 境界選点 & 境界条件 & 境 界 条 件 式 & 境界条件式のマトリックス表示 & 列べトル $\boldsymbol{x}_{3} \cdot \boldsymbol{x}_{4}$ の要素 $w_{n m}$ に対応する $\boldsymbol{b}_{r}$ の要素 \\
\hline \multirow[t]{3}{*}{$\begin{array}{l}x= \pm \frac{l}{2} \text { 上の } \\
\text { 境界選点 }\end{array}$} & 固 定 端 & $\begin{array}{l}w=0 \\
\frac{\partial w}{\partial x}=0\end{array}$ & $\begin{array}{l}b_{7}(x, y) x_{3}+b_{8}(x, y) \cdot x_{4}=0 \\
b_{9}(x, y) x_{8}+b_{10}(x, y) \cdot x_{4}=0\end{array}$ & $\begin{array}{l}P_{n}(\alpha x) \cdot P_{m}(\beta y) \\
\alpha P_{n^{\prime}}(\alpha x) \cdot P_{m}(\beta y)\end{array}$ \\
\hline & 自由 端 & $\begin{array}{l}M_{x}=-D\left(\frac{\partial^{2} w}{\partial x^{2}}+\nu \frac{\partial^{2} w}{\partial y^{2}}\right)=0 \\
V_{x}=-D \frac{\partial}{\partial x}\left\{\frac{\partial^{2} w}{\partial x^{2}}+(2-\nu) \frac{\partial^{2} w}{\partial y^{2}}\right\}=0\end{array}$ & $\begin{array}{l}b_{11}(x, y) x_{3}+b_{12}(x, y) \cdot x_{4}=0 \\
b_{13}(x, y) x_{3}+b_{14}(x, y) \cdot x_{4}=0\end{array}$ & $\begin{array}{l}\alpha^{2} P_{n}^{\prime \prime}(\alpha x) \cdot P_{m}(\beta y)+\nu \beta^{2} P_{n}(\alpha x) \cdot P_{m}^{\prime \prime}(\beta y) \\
\alpha^{8} P_{n^{\prime \prime \prime}}^{\prime \prime}(\alpha x) \cdot P_{m}(\beta y) \\
\quad+(2-\nu) \alpha \beta^{2} P_{n^{\prime}}(\alpha x) \cdot P_{m}^{\prime \prime}(\beta y)\end{array}$ \\
\hline & 単純支持 & $\begin{array}{l}M_{x}=0 \\
w=0\end{array}$ & $\begin{array}{l}b_{11}(x, y) x_{3}+b_{12}(x, y) \cdot x_{4}=0 \\
b_{7}(x, y) x_{3}+b_{8}(x, y) x_{4}=0\end{array}$ & $\begin{array}{l}\alpha^{2} P_{n}^{\prime \prime}(\alpha x) \cdot P_{m}(\beta y)+\nu \beta^{2} P_{n}(\alpha x) \cdot P_{m}^{\prime \prime}(\beta y) \\
P_{n}(\alpha x) \cdot P_{m}(\beta y)\end{array}$ \\
\hline \multirow[t]{3}{*}{$\begin{array}{l}y= \pm \frac{b}{2} \text { 上の } \\
\text { 境界選点 }\end{array}$} & 固 定 端 & $\begin{array}{l}w=0 \\
\frac{\partial w}{\partial y}=0\end{array}$ & $\begin{array}{l}b_{7}(x, y) x_{3}+b_{8}(x, y) x_{4}=0 \\
b_{15}(x, y) x_{3}+b_{16}(x, y) x_{4}=0\end{array}$ & $\begin{array}{l}P_{n}(\alpha x) \cdot P_{m}(\beta y) \\
\beta P_{n}(\alpha x) \cdot P_{m^{\prime}}(\beta y)\end{array}$ \\
\hline & 自 由 端 & $\begin{array}{l}M_{y}=-D\left(\frac{\partial^{2} w}{\partial x^{2}}+\nu \frac{\partial^{2} w}{\partial y^{2}}\right)=0 \\
V_{y}=-D \frac{\partial}{\partial y}\left\{\frac{\partial^{2} w}{\partial y^{2}}+(2-\nu) \frac{\partial^{2} w}{\partial x^{2}}\right\}=0\end{array}$ & $\begin{array}{l}b_{17}(x, y) x_{3}+b_{18}(x, y) x_{4}=0 \\
b_{19}(x, y) x_{3}+b_{20}(x, y) x_{4}=0\end{array}$ & $\begin{array}{l}\beta^{2} P_{n}(\alpha x) \cdot P_{m}^{\prime \prime}(\beta y)+\nu \alpha^{2} P_{n}^{\prime \prime}(\alpha x) \cdot P_{m}(\beta y) \\
\beta^{3} P_{n}(\alpha x) \cdot P_{m^{\prime \prime \prime}}(\beta y) \\
\quad+(2-\nu) \alpha^{2} \beta P_{n}^{\prime \prime}(\alpha x) \cdot P_{m}^{\prime}(\beta y)\end{array}$ \\
\hline & 単純支持 & $\begin{array}{l}M_{y}=0 \\
w=0\end{array}$ & $\begin{array}{l}b_{17}(x, y) x_{3}+b_{18}(x, y) x_{4}=0 \\
b_{7}(x, y) x_{3}+b_{8}(x, y) x_{4}=0\end{array}$ & $\begin{array}{l}\beta^{2} P_{n}(\alpha x) \cdot P_{m}^{\prime \prime}(\beta y)+\nu \alpha^{2} P_{n}^{\prime \prime}(\alpha x) \cdot P_{m}(\beta y) \\
P_{n}(\alpha x) \cdot P_{m}(\beta y)\end{array}$ \\
\hline
\end{tabular}
ベクトルの要素数が $4 \times(N+M+4)$ となるだけで, あ とはそれぞれ $\boldsymbol{a}_{3}, \boldsymbol{c}_{3}$ と同一の式で表わすことができる.

\section{付録 $\mathbf{A} \cdot 4$}

1) 井口鹿象: 相対する 2 辺が単純支承他の 2 辺が自由なる 矩形板の振動について, 土木学会誌, 第 26 巻, 第 4 号, pp. 427 440, 1940.4 .

2) Merser, C.A. and Server, M.C. : Prediction of Natural Frequencies and Normal Modes of Skin-Stringer Panel Rows, Journal of Sound Vib., 6(1), pp. 149 165, 1967.

3) Leissa, A.W., Clausen, W.E., Hubbert, L.E. and Hopper, A.T. : A Comparison of Approximate Methods for the Solution of Plate Bending Problems, AIAA, No. 68 296, 1968.

4) Warburton, G.B. : The Vibration of Rectangular Plates, Proceeding of the Institution of Mechanical Engineers, Vol. 12, No. 12, pp. 371 384, 1954.

5) Yang, W.H. : Vibration of a Plate with Internal Constraints, Journal of Applied Mechanics, pp. 1072 1074, 1974.

6) Cheung, Y.K. and Cheung, M.S. : Flexural Vibration of Rectangular and Other Rolygonal Plates, Journal of ASCE, Vol. 97, EM 2, pp. 391 411, 1971.

7）中村秀治 : 断面変形を考慮した薄肉はりの振動解析, 士 木学会論文報告集, 第 223 号, pp. 11 22, 1974.

8）能町純雄・角田与史雄・岸 徳光: 薄肉 $\mathrm{H}$ 形断面ばりの 弾性波の位相速度について,土木学会論文報告集, 第 244 号, pp. 37 45, 1975.

9) Hooker, R.J. and O'Briei, D.J. : Natural Frequencies of Box-Type Structures by a Finite-Element Method, Journal of Applied Mechanics, pp. 363 365, 1974.

10) Lees, A.W., Thomas, D.L. and Wilson, R.R. : Analysis of the Vibration of Box Beams, Journal of Sound Vib., 45(4), pp. 559 568, 1976.

11) Finlayson, B.A. : The Method of Weighted Residual and Variational Principles, Academic Press, 1972.

12) Prenter, P.M. : Splines and Variational Methods, John Wiley \& Son.

13）川井忠彦：重みつき残差法と有限要素法の将来性, 数理 科学, No. 144, pp. 5 11, June, 1975.

14) A.I. Soler : Higher-Order Theories for Structural Analysis Using Legendre Polynomial Expansions, Journal of Applied Mechanics, pp. 757 762, 1969.

15）寺沢寛一：自然科学者のための数学概論, 岩波書店, 1954 .

16）末岡清市: 級数および直交関数系, コロナ社, 1957.

17) スミノルフ : 高等数学教程 II 巻第一分冊, 共立出版, 1959.

18) Timoshenco, S. and Woinowsky-Krieger : Theory of Plates and Shells, 2nd ed., McGrow-Hill, 1959.

19）栖原二郎：平板の曲げ理論，コンピューターによる構造 工学講座 II-5-A, 培風館, 1972.

20) Timoshenco, S. and Goodier, J. : Theory of Elasticity 3rd ed., McGrow-Hill, 1970.

21) Wilkinson, J.H.: The Algebraic Eigenvalue Problem, Clarendon Press, Oxford, 1965.

(1977.7.22 - 受付) 